\title{
SIRF HAREKET SUÇU SOYUT TEHLIKE SUÇU MUDUR?
}

\author{
Elvan KEÇELİOĞLU*
}

\section{$\ddot{O} Z$}

Zarar ve tehlike suçları ile sirf hareket suçları ve neticeli suçlara ilişkin teorik sorulara cevap verilmesi, hem yasa koyucuya yol göstermesi hem de suçun işlendiği yer, zamanaşımı, teşebbüs gibi bazı ceza hukuku kurumlarının uygulaması açısından büyük önemi haizdir. Özellikle zarar ve tehlike suçlarl ayrımının hangi ölçüt üzerinden yapılacağl ve sırf hareket suçlarının soyut tehlike suçu olup olmadığl sorularına verilen cevaplar, bu sorunlara tatmin edici bir çözüm sunmaktan uzaktır. Bu çalışma kapsamında savunulan düşünce, zarar ve tehlike suçları ayrımının maddi konu değil, hukuki konunun objesi kavramını da içerisine alan bir suçun konusu kavramından hareketle yapılması gerektiğidir. Bu şekilde her sırf hareket suçunun bir soyut tehlike suçu olduğu, ancak her soyut tehlike suçunun zorunlu olarak sirf hareket suçu olmadı̆̆ sonucuna varllacaktır.

Anahtar Kelimeler: Sırf hareket suçları, tehlike suçları, suçun maddi konusu, suçun hukuki konusu, hukuki konunun objesi.

\section{IS CONDUCT CRIME AN ABSTRACT ENDANGERMENT CRIME?}

\section{Abstract}

Answering the theoretical questions about the endangerment and harm crimes, and also result and conduct crimes have critical importance for guiding the legislator as well as for applying some criminal law concepts, such as the place of commission of offence, the statute of limitation and attempt. Answers to the following questions in the literature are indeed far from offering satisfying solutions: Which criteria shall be used to distinguish the endangerment crimes and harm crimes? Whether conduct crimes are abstract endangerment crimes or not?

The opinion developed in this study is that the basis of the distinction between harm crimes and endangerment crimes shall not rely on the object of crime, but rather on the legally protected interest. In this way, it will be concluded that every conduct

\footnotetext{
Doç. Dr., Çankaya Üniversitesi, Hukuk Fakültesi, Ceza ve Ceza Muhakemesi Hukuku Anabilim Dal1/ ANKARA, e-posta: elvan@cankaya.edu.tr,

ORCID : 0000-0002-3081-1344

DOI : 10.34246/ahbvuhfd.933579

\section{Yayın Kuruluna Ulaştığı Tarih : 26/10/2020}

Yayınlanmasının Uygun Görüldüğü Tarih: 28/04/2021
} 
crime is also abstract endangerment crime, but every abstract endangerment crime is not necessarily a conduct crime.

Keywords: conduct crimes, endangerment crimes, material object of crime, legally protected interest by crime, object of the legally protected interest.

\section{Giriş}

Ceza hukukunda bir kurumun hukuki niteliğinin belirlenmesi, ona uygulanacak ilke ve kuralların tespiti bakımından önem arz etmektedir. Soruşturma konusu fiil belirlendikten sonra, bu fiilin, işlendiği iddia edilen suçun tipik fiilini oluşturup oluşturmadığı ve suçun unsurlarının somut olayda gerçekleştirilip gerçekleştirilmediği sorunuyla karşılaşılmaktadır. Bu sorunun çözümünün -normatif metodolojik uygulamanın- esasen hukuk fakültelerinde yapılan eğitim ile kazanılması beklenmekte ve bu iş, ceza hukukçusu için emekli olduğu güne kadar devam eden mesleki bir uğraş olarak karşımıza çıkmaktadır. Ancak ceza hukukunun doğrudan toplumsal hayattan da etkilenen teorik gelişim sürecine paralel olarak suç tipleri de gelişmektedir. $\mathrm{Bu}$ bağlamda neticeli suçlar olarak adlandırılan ve suçun maddi unsurunun hareket- netice- illiyet bağı şeklinde ortaya çıktığ1 "kasten öldürme", "mala zarar verme" gibi klasik suç tiplerinin yanı sıra; sırf hareket suçlarının ceza hukuku dünyasında bulunması ve ayrıca tehlike suçları olarak adlandırılan suç tiplerinin sanayileşme ve şehirleşme ile birlikte ortaya çıkarak alana dâhil olmaları, yukarıda bahsettiğimiz mesleki uğraşıyı daha karmaşık bir hâle getirmektedir.

Bahsedilen işin zorluğunun, bazen kanun yazımı aşamasında karşımıza çıkan bilgisizlik ve eksiklikten kaynaklandığı görülmektedir. Özellikle, özel ceza kanunları ile ceza içeren özel kanunların kaleme alınmasında temel ceza kanunları kadar hassas davranılmadığı gözlemlenmektedir. Panik kanunlaştırma serüvenine bürokratik bilgi eksikliğinin de eşlik etmesiyle durum içinden çıkılmaz bir hâl alabilmektedir. Bu karmaşıklık; kimi zaman ceza hukuku siyaseti ilkelerinden vazgeçiş, kimi zaman ise ceza hukuku sistemini çökertme pahasına ceza hukukuna yabancı kurumların esasen suç ve ceza içeren normlar şeklinde ihdası elzem olan alana dâhil edilmesinden doğmaktadır. ${ }^{1}$

1 Burcu Ertem, “Ceza Hukukuna Hakim Olan İlkeler Açısından Bankacılık Zimmeti Suçu”, 
Böylesi bir karmaşıklıktan kaçınabilmek, ilk olarak sorunun "cezai sorumluluğun belirlenmesi" olduğu bilincinden hareketle, kanunlar ve özel hükümlerde gösterilen suç tiplerinin, belli bir bilimsel tutarlılık içerisinde kaleme alınmasını gerektirmektedir. Söz konusu faaliyet, her şeyden önce kanun koyucuya yüklenmiş bir ödev olarak karşımıza çıkmaktadır. ${ }^{2}$ Dolayısıyla konumuz bağlamında kanun koyucu bir suç tipini neticeli bir suç veya sırf hareket suçu olarak belirleyecekse bunu önceden düşünmeli ve ilgili kuruma ait ilkelerin farkında olarak suç tipini kaleme almalıdır. Bu, basit bir temenniden öte, kanunilik ilkesinin bir unsuru olan belirlilik (lex certa) ilkesinin kanun koyucuya yüklediği ödevin gereğidir. ${ }^{3}$ Fakat söz konusu bağlamda kanun koyucunun işi de sanıldığı kadar kolay değildir. Çünkü belli bir fiili suç hâline getiren kanun koyucu, farklı suç tiplerini ve suçun farklı kategorilerini içerisine alan "çatı/düzenleme" yapma mecburiyetindedir. Bir suç aynı anda "sırf hareket suçu”, "özgü suç", "cinsel özgürlük aleyhine bir suç" ve "kasıttl bir suç" olabilmektedir. ${ }^{4}$ Bu durum, anılan kavramlara ilişkin farklı bilimsel bilgilerin farkındalığını mecburi kılmaktadır. En basit örneğiyle kanun koyucu bir somut tehlike suçu vazetmek isterse suçun formülasyonunda "tehlike" kavramını bir şekilde kullanma mecburiyeti altındadır. ${ }^{5}$ Suçu, taksirli bir şekilde düzenleyecek ise "taksir" ya da "tedbirsizlik veya dikkatsizlik" kavramını tehlike kavramıyla beraber kullanmalıdır. Ancak zaten karmaşık olan suç genel teorisi mimarisi olarak niteleyebileceğimiz bu işlem; suçun "tipikliği kaldıran rıza" veya "objektif cezalandırma şartları" gibi diğer unsurlarının da işin içerisine girmesiyle, teorik bilginin azlığı veya bu bilginin farkındalığının eksikliği sonucu sanılandan daha da meşakkatli olabilmektedir.

5. Türk-Kore Ceza Hukuku Günleri Karşılaştırmalı Hukukta Ekonomik Suçlar Uluslararası Sempozyumu, Ankara, 23.09.2019, s. 3.

2 Suç siyaseti ve ceza hukuku arasındaki ilişki ve kanun koyucunun cezalandırılabilir alanı belirleme konusundaki takdir yetkisinin anayasal sınırları için bkz. Hilal Düzenli, "Yasa Koyucunun Suç ve Ceza Siyasetini Belirleme Yetkisinin Anayasal Denetimi", 2020, 5 (1), Çankaya Üniversitesi Hukuk Fakültesi Dergisi, Arş. Gör. Ceren Damar Şenel Armağanı, s. $1191 \mathrm{vd}$.

3 Ceza hukukunda dilin biçimi ve bu bağlamda kanunilik ilkesine ilişkin tartışmalar için bkz. Elvan Keçelioğlu, "Ceza Hukukunda İçtihadın Sınırı, Yorum ve Kıyas”, 2012, Y. 3, (11), TAAD, s. 82.

4 Thomas Rönnau, "Grundwissen - Strafrecht: Erfolgs- und Tätigkeitsdelikte", 2010, 11, JuS, s. 961.

5 Andreas Hoyer, Strafrecht Allgemeiner Teil, 1. Bas1, Hermann Luchterhand Verlag, 1996, s. 29. 
$\mathrm{Bu}$ çalışmada, teoride ve uygulamada çokça karşımıza çıkan ancak birçok kez birbirinin yerine kullanılan "sırf hareket suçlarının" "soyut tehlike suçu" olup olmadıkları sorusu, yukarıda açıklanan perspektiften cevaplandırılmaya çalışılacaktır. Sorunun cevabı için öncelikle bazı temel kavramların hatırlanmasinda zaruret bulunmaktadır.

\section{Sırf Hareket Suçları ve Neticeli Suçlar Ayrımının Anlamı}

\section{A. Netice Kavramı}

Sırf hareket suçu ile neticeli suç ayrımına geçmeden önce, ceza hukukunda "netice" (sonuç) kavramının ne anlama geldiği üzerinde durulmalıdır. Çünkü esasen yazıya konu ayrım, netice kavramı üzerinden yapılmaktadır. Ceza hukukunda neticeye dair iki farklı anlayış olduğu söylenebilir. ${ }^{67}$ Bunlardan ilki neticenin "doğalcı" anlayışı, ikincisi ise neticenin "hukuki" anlayışıdır.

"Doğalcı netice anlayışı"na göre netice, insan davranışının doğal bir sonucudur. Dış dünyada meydana gelir ve illiyet bağı ile insan davranışına bağlanabilir. Bu yönüyle netice, ceza hukukunda hareketten farklı ve ondan ayrılabilen ancak hareket ile bağlantısı bulunan bir olgu olarak karşımıza çıkmaktadır. Dolayısıyla teknik tanım itibari ile netice, insan davranışının dış dünyada meydana getirdiği ve hukuk düzeninin cezai sonuçlar bağlamak suretiyle nazara aldığı doğal değişiklik olarak anlaşılmaktadır. Bu tez; sadece

6 Sonucun hukuki niteliği hakkında esasen pek çok kuram bulunmaktadır. Örneğin kimi yazarlarca netice; doğal sonuç, tehlike kuramı, sonuçsuz suç kuramı, kuralcı kuram ve ümanist kuram olarak beş ayrı başlık altında incelenmektedir. Ayrıntılı bilgi için bkz. Faruk Erem / Ahmet Danışman / M. Emin Artuk, Ceza Hukuku Genel Hükümler, 1. Bası, Seçkin Yayınevi, 1997, s. 268.

7 Neticenin suçun unsurları içerisindeki yeri konusundaki tartışmalar için bkz. Mahmut Koca / İlhan Üzülmez, Türk Ceza Hukuku Genel Hükümler, 12. Bası, Seçkin Yayınevi, 2019, s. 126 vd., Taksirli suçlar açısından yapılan bir çalışma için bkz. Uğur Ersoy, "Hareketin ve Neticenin Haksızlığı Kavramları Işı̆̆ında Taksirli Suçlarda Meydana Gelen Sonucun Hukuki Niteliği Üzerine Bir İnceleme”, 2018, 13 (36), CHD.

8 "Neticenin esası, mahiyeti ve suçun zorunlu unsuru olup olmadığı konusunda doktrinde fikir birliği bulunmamaktadır. Netice, bir kısım müelliflerce tabii olgulardan hareketle izah edilirken (tabii netice anlayışı), diğer bir kısım müelliflerce ise normatif bir esastan hareketle izaha çalışılmıştır (hukuki netice anlayış1). Yine neticeyi tabii bir olgu olarak izah eden müelliflerce netice kavramına verilen anlamlar farklıdır. Bir kısım müellifler fiilin sebep olduğu, kanuni tipte yer alan ve dış dünyada meydana gelen her türlü tabii değişikliği netice addederken (geniş anlamda netice telakkisi); bir kısım müellifler, bunlardan yalnızca kanuni tipte suçun unsuru olarak yer alan değişiklikleri netice kabul etmektedirler (dar anlamda netice telakkisi”). Ayrıntılı açıklamalar için bkz. Selim Erdin, Ceza Hukukunda İlliyet, Marmara Üniversitesi Sosyal Bilimler Enstitüsü Basılmamış Yüksek Lisans Tezi, 2013, s. $34 \mathrm{vd}$. 
kurucu unsur olan neticeler açısından değil, netice sebebiyle ağırlaşan suçlarda meydana gelen neticeler ile cezayı ağırlaştıran neticeler açısından da geçerlidir. ${ }^{9}$ Neticeyi ortaya çıkaran insan davranışının icrai veya ihmali olması arasında bir fark yoktur. ${ }^{10}$ Ayrıca hareketin taksirli veya kasıtlı işlenmesinin önemli olmadığı da eklenmelidir. Dış dünyada hâsıl olan bu değişikliğin, mala zarar verme suçunda (TCK. m. 151) olduğu gibi fiziki (maddi), öldürme suçunda (TCK. m. 81) olduğu gibi fizyolojik ya da cinsel saldırı suçunun neticesi sebebiyle ağırlaşmış hallerinden biri olan, bitkisel hayata girme gibi değişiklik olması mümkündür. Doğalcı anlayış esas alındığında, neticenin her suçta mutlaka bulunması gereken bir unsur olmadığı sonucuna ulaş1ır. Zira hareketten ayrı olması icap eden netice, sadece bazı suç tiplerinde (maddi suçlar) mevcutken, diğer bazı suç tiplerinde (şekli suçlar) mevcut değildir. Nitekim kanun, suçun mevcudiyeti bakımından, bazı suç tiplerinde fiilin akabinde ve ondan ayrı bir neticenin gerçekleşmesini ararken, bazı suç tiplerinde ise sadece muayyen bir fiilin işlenmesini kâfi görmekte, ayrıca bu fiille illi münasebet içinde ve ondan ayrı bir neticenin de hâsıl olması aranmamaktadır. Birinciler "neticeli suçlar" veya "maddi suçlar" şeklinde ifade edilirken, ikinciler "neticesiz suçlar", "şekli suçlar" veya "sırf hareket suçları" şeklinde ifade edilmektedir."

Neticeye ilişkin diğer anlayış ise doktrinde "neticenin hukuki anlayışı" olarak adlandırılmaktadır. Bu görüşe göre netice; davranış ile normun koruduğu menfaatin veya varlığın, zarar veya tehlike şeklinde ihlal edilmesinden

9 Nevzat Toroslu / Haluk Toroslu, Ceza Hukuku Genel Kısım, 25. Bası, Savaş Kitabevi, 2019, s. 142; Harro Otto, Grundkurs Strafrechts, 7. Bas1, de Gruyter, 2004, s. 41, kn. 8. Bu görüş, tehlike kavramını açıklayamaması dolayısıyla doktrinde tartışmalara neden olmuş ve ihtiyaçtan daha dar bir netice kavramını izah ettiği için kimi yazarlarca reddedilmiştir. Bkz. Erem / Danışman / Artuk, s. 268.

10 Timur Demirbaş, Ceza Hukuku Genel Hükümler, 14. Bas1, Seçkin Yayınevi, 2019, s. 241.

11 Neticeli suçlarda kanun, bir neticenin husule getirilmesini cezalandırmaktadır. Sırf hareket suçlarında ise bir neticenin husulle getirilmesini değil, gerçekleştirilen belirli bir davranışı (fiili) cezalandırmaktadır. Neticeli suçlara öldürme (TCK. m. 81), yaralama (TCK. m. 86), mala zarar verme (TCK. m. 151) suçları misal gösterilebilir. Kanuni tipte suçun oluşması için sadece fiilin ikasının kâfi olduğu ve herhangi bir neticenin gerçekleşmesinin aranmadığ sırf hareket suçlarına misal olarak ise hakaret (TCK. m. 125), hırsızlık (TCK. m. 141), suçu bildirmeme (TCK. m. 278) ve yalan tanıklık (TCK. m. 272) suçları gösterilebilir. Erdin , s. 35. vd. 
ibarettir. ${ }^{12}$ Başka bir ifadeyle, hukuki konunun ihlalidir. ${ }^{13}$ Bu görüş, neticenin esasını tabii olgularda değil, normlarda aramaktadır. Buna göre netice, failin fiilinin bir sonucu olarak dış dünyada meydana gelen tabii hadiselerden değil, aksine, bu fiilin ihlal edici etkisinden ibarettir. Hukuk düzeni, vazedilen normlar vasıtasıyla kişilerin hak ve menfaatlerini ve hukuki değerleri korumayı amaçlamaktadır. Bu manada ceza hukukunun da gayesi, bütün hak ve menfaatleri olmasa dahi, hakkında suç ihdası lüzumlu görülen hukuki değerlerin korunmasıdır. Ceza hukuku açısından önemli olan, söz konusu hukuki değer yahut hakların ihlalidir. Bu ihlal, başlı başına bir neticedir. ${ }^{14}$ Ayrıca neticenin normatif anlayışına göre, normun ihlali, şayet failin fiiliyle sebep olduğu diş dünyadaki bir değişiklik dolayısıyla gerçekleşiyorsa veya suçun oluşmasında fiilden ayrı olarak tabii âlemde bir değişikliğin de vaki olmasını arıyorsa, bu halde söz konusu tabii değişiklik ya da hadise gerçekleşmeden, ihlal de gerçek anlamda ortaya çıkmayacağından, suç da gerçekleşmiş olmaz. $\mathrm{Bu}$ suçlar, neticesi hareketten ayrı suçlardır. Buna karşılık, ceza normunun ihlal edilmiş olması için, suçun kanuni tarifinde failin fiilinden ayrı olarak gerçekleşen tabii bir değişiklik veya hadisenin husule gelmesi aranmamış ve fiilin icrası ile normun ihlal edilmiş olması tek başına kâfi görülmüş ise bu halde söz konusu fiilin gerçekleştirilmesiyle suç da tamam olur. Bu suçlar ise doktrinde neticesi harekete bitişik suçlar olarak tanımlanmaktadır. Hukuki netice anlayışına göre, zarar suçları ve somut tehlike suçları neticesi hareketten ayrılabilen suçlardır ve maddi suç kategorisine dâhil edilmektedir. ${ }^{15}$ Soyut tehlike suçları ise, neticesi harekete bitişik suçlardır ve şekli suç veya sırf hareket suçu kategorisine dâhil edilmektedirler. Ancak doktrinde neticenin hukuki anlayışına ciddi eleştiriler yöneltilmiştir.

İlk eleştiri, her suçun zaten bir hukuki konuyu ihlal edeceği, bu itibarla sırf hareket suçu ile neticeli suçlar arasındaki ayrımın anlamsızlaşacağı ve işlevsizleşeceği yönündedir. Çünkü hukuki konunun ihlali, bütün suçların

12 Johannes Kaspar, Strafrecht Allgemeiner Teil, 3. Bası, Nomos, 2019., s. 48; Doğan Soyaslan, Ceza Hukuku Genel Hükümler, 8. Bası, Yetkin Yayınevi, 2018. s. 254. Dönmezer / Erman, hukuki konunun ihlali başlı başına bir netice olduğundan hareket ile neticesi harekete bitişik suçlarda neticenin başlı başına ihlal olduğu görüşündelerdir. Neticesi hareketten ayrılan suçlarda ise bu neticenin yanı sıra bir de doğal anlamda neticenin gerçekleşmesi gerektiği görüşü de yine söz konusu yazarlarca savunulmaktadır. Bkz. Sulhi Dönmezer / Sahir Erman, Nazari ve Tatbiki Ceza Hukuku, Genel Kısım, C. I, 1. Bası, Beta Basım, 1997, s. 384.

13 Hoyer, s. 29.

14 Erdin, s. 36. vd.

15 Erdin, s. 37. 
ortak özelliği olarak karşımıza çıkmaktadır. ${ }^{16} \mathrm{Bu}$ bağlamda bir netice olarak hukuki konunun ihlali, çocukların cinsel istismarı gibi sırf hareket suçları bakımından da söz konusudur. ${ }^{17}$ Örneğin; 5237 sayılı Türk Ceza Kanunu’nun (TCK) 105. maddesinde düzenlenen cinsel taciz suçunun çocuğa karş1 işlenmesi hâlinde, cinsel taciz olarak nitelendirilebilecek bir davranışın çocuğa karşı yapılmasıyla suç gerçekleşir ve çocuğun engelsiz cinsel gelişim hakkı ihlal edilir. Neticenin ihlal olarak algilandığı bu gibi durumlarda, sırf hareket suçu ile neticeli suçlar arasındaki ayrım anlamsızlaşmaktadır. ${ }^{18}$ Öte yandan normatif anlamda netice kavramı sadece zarar suçlarında uygulama bulabilmektedir. Zira her suçta neticenin gerçekleşmesi ile hukuki değer ve bu hukuki değerin korumaya aldığı nesne zarara uğramış olmaz. Bu sırf hareket suçları ile neticeli suçlar ve zarar ve tehlike suçlarındaki ayrımın sanılanın aksine birbirinden farklı bakış açılarına dayanmasının bir sonucudur. ${ }^{19}$

Ayrıca doktrinde gösterildiği gibi netice; nedensellik bağı, suça teşebbüs, ihmal suretiyle icra suçları bağlamında ihlal şeklinde değil doğal anlamıyla ele alınmalıdır ve ancak bu şekilde anlaşılan bir netice ceza hukukunda bir işlev üstlenebilir. Sonuç itibariyle neticenin hukuki anlayışı kabul edilemez. ${ }^{20}$ Ayrıca neticenin sırf ihlal şeklinde ele alınmasının, netice sebebiyle ağırlaşmış suçları açıklamakta göstereceği zafiyet de eklenmelidir. Nitekim TCK bakımından bir inceleme yapıldığında; 8., 22. ve 23. maddelerde netice kavramına yer verilirken teşebbüse ilişkin 35. madde kapsamında neticeye yer verilmediği görülmektedir. Dolayısıyla kanun koyucunun netice açısından "doğal anlamda netice" kavramından hareket ettiğini söylemek pek tabii mümkündür. ${ }^{21} \mathrm{Bu}$ bağlamda tipik netice ile hukuki (konu/) değerin ihlalinin, iki ayrı ceza hukuku terimi olduğunu belirtmek gerekir. Hareketten zaman ve mekân olarak ayrılabilen netice, suçun konusunun zarara veya tehlikeye uğratılmasıdır. Buna karşın hukuki değerin ihlali, tipik hareketin ceza normu

16 Nevzat Toroslu, Cürümlerin Tasnifi Bakımından Suçun Hukuki Konusu, 1. Bası, Savaş Yayınevi, 2019, s. 196.

17 Günther Stratenwert / Lothar Kuhlen, Strafrecht Allgemeiner Teil, 6. Bas1, Vahlen, 2011, s. 76; Hans-Heinrich Jescheck / Thomas Weigend, Lehrbuch des Strafrechts, Allgemeiner Teil, 5. Bask1, Duncker \& Humblot, 1996, s. 263.

18 Stratenwerth / Kuhlen, s. 76.

19 Ingke Goeckenjan, Revision der Lehre von der objektiven Zurechnung, 1. Bas1, Mohr Siebeck, 2017, s. 49.

20 Toroslu / Toroslu, s. 144. Aksi yöndeki görüş için bkz. Dönmezer / Erman, s. 384.

21 Zeki Hafizoğulları / Muharrem Özen, Türk Ceza Hukuku Genel Hükümler, 12. Bası, Us-A Yayınları, 2019, s. 176. 
ile koruma altına alınmış değer ile çatışması olarak tanımlanmaktadır. ${ }^{22}$

\section{B. Sırf Hareket Suçu - Neticeli Suç Ayrımı}

İzah edilen sebeplerle doktrinde neticenin "doğalcı" anlayışı üstün tutulmaktadır. Bu belirlemenin ardından şu iddia ortaya atılabilir: Bir suçun sırf hareket suçu mu yoksa neticeli bir suç mu olduğuna ilişkin ayrım, tipiklik unsurunun analizinden ortaya çıkmaktadır. Buna göre neticeli suçlar, suç tipinde gösterilen hareketin yanı sıra bu hareketten hasıl olan, mekânsal ve zamansal olarak ya da en azından mantıksal ve kavramsal olarak hareketten ayrılabilen dış dünyadaki bir değişikliği şart koşmaktadır. Neticeli suçlar için akla gelen ilk örnekler, insan öldürme (TCK m. 81) ve yaralama suçlarıdır (TCK m. 86). Bu bağlamda somut tehlike suçları da ceza kanunlarında bir tehlike neticesi öngörülmüş olması nedeniyle hareket, netice ve illiyet bağından oluşan bir yapıya sahiptir ve neticeli suçlar kategorisinde yer alır. $\mathrm{Bu}$ yapıyı içeren suç tipleri kanun koyucu tarafından sıklıkla kullanılmakta ve hukuk dünyasının geneli tarafından suçun unsurları denildiğinde esasen bir neticeyi de içeren söz konusu yapı anlaşılmaktadır. ${ }^{23}$

Neticeli suçların yanı sıra modern ceza kanunları başka bir temel suç tipi daha tanımaktadır. Hareketin yapılmasıyla veya ihmal ile suçun maddi unsurlarının gerçekleştirilmiş sayılacağı ve yukarıda gösterildiği gibi bir neticenin bulunmasının kanunda öngörülmediği bu suç tipleri, ceza hukuku doktrininde "sırf/salt hareket suçları" olarak tanımlanmaktadır. ${ }^{24}$ Özellikle bizzat işlenebilen suçların" ${ }^{25}$, sırf hareket suçları şeklinde işlenmesi çok sık karşılaşılan bir durumdur. Anılan suçlarda kanunda gösterilen hareketi kendisi gerçekleştiren kişi fail olarak hareket etmiş ve suçu gerçekleştirmiş olur. Örneğin, Alman Ceza Kanunu'nun (AlCK) 153. maddesinde düzenlenen yalan tanıklık bizzat işlenebilen bir suç niteliğindedir. $\mathrm{Bu}$ maddeye göre yetkili merci huzurunda yalan tanıklık yapan kişi, suçun maddi unsurlarını bizzat gerçekleştirmiş kabul edilmektedir. ${ }^{26}$ Yalan tanıklık suçunun işlenmesi neticesinde bir kişinin mahkûmiyetine sebep olunması, suçun gerçekleşmesi

22 Jescheck / Weigend, s. 263. Bu bağlamda netice hareketten hasıl olan ve hareketi aşan, tipiklikte yer alan etkiler olarak tanımlanmalıdır. Stratenwerth / Kuhlen, s. 76.

23 Aynı yönde bkz. Rönnau, s. 962.

24 Rönnau, s. 962. OTTO, s. 41, kn. 8.

25 Bizzat işlenebilen suçlar hakkında bilgi için bkz. Berrin Akbulut, Ceza Hukuku Genel Hükümler, 6. Bası, Seçkin Yayınevi, 2020, s. 413 vd.

26 Rönnau, s. 962. 
açısından önemli değildir. ${ }^{27}$ Aynı şekilde, sarhoş bir şekilde araç kullanmayı düzenleyen 316. madde uyarınca, araç idare edemeyecek durumda olmasına rağmen araç kullanan kişi, sırf bu hareketi yapmış olması nedeniyle suçun maddi unsurlarını gerçekleştirmiş kabul edilir. ${ }^{28}$ Bizzat işlenen bazı suçları da içerisine alan bir şekilde sırf hareket suçlarına Türk Ceza Kanunu'ndan hakaret (TCK m. 125), tehdit (TCK m. 106), iftira (TCK m. 267) ve yalan tanıklık (TCK m. 272) suçları örnek gösterilmektedir. ${ }^{29}$

Hemen belirtelim ki, sorun esasen bu kadar açık ve net değildir. Özellikle Alman doktrininde sırf hareket suçları denilen bir kategorinin ceza hukuku dünyasında var olup olmadığı konusunda güncel tartışmalar yapılagelmektedir. Alman doktrininde öncelikle suçların sırf hareket suçu ve neticeli suçlar olarak temelde ikiye ayrılması konusunda bir görüş birliği olduğu söylenemez. Ayrımı reddedenlerin çıkış noktası, özellikle sırf hareket suçlarına ilişkin betimlemelerdir. Ayrımı reddeden yazarlara göre esasen "sırf hareket suçu" diye bir suç tipi bulunmamaktadır. Çünkü sırf hareket suçlarında da temel olarak harekete bağlanan bir dış etki vardır. Örneğin yukarıda sırf hareket suçlarına örnek verilen "yalancı tanıklık suçunda", suçun gerçekleşebilmesi için "ifade" hâkim tarafından duyuları itibari ile algılanmış/ idrak edilmiş ve hem hâkim hem de tanık açısından tamamlanmış olmalıdır. Benzer yönde, "sarhoş şekilde araç kullanma" fiili için sürücünün direksiyona oturması yeterli değildir. Ayrıca failin, fiilen aracı hareket ettirmiş olması hareketin bir koşulu olarak karşımıza çıkmaktadır. Bu açıdan esasen neticesiz suçlar diye bir suç tipi bulunmamaktadır. ${ }^{30}$ Türk doktrininde de buna benzer görüşler savunulmaktadır. Neticeyi hukuki değerin ihlali olarak kabul eden kimi yazarlar, neticesiz suç olamayacağ 1 ve her suçta harekete bitişik veya ondan ayrı muhakkak bir neticenin bulunduğu görüşündedirler. ${ }^{31}$ Ancak dikkat edilmelidir ki Alman hukukundaki görüşlerin farkı, bizatihi doğal anlamda netice kavramını kabul etmelerine rağmen neticesiz suçların olamayacağı iddialarını getirmesidir.

27 Otto, s. 41.

28 Rönnau, s. 962; Otto, s. 41, kn. 8.

29 Akbulut, s. 414.

30 Rönnau, s. 962. Alman hukukunda sırf hareket suçu diye bir suçun olmayacağı görüşü için bkz. Tonio Walter, "Das Märchen von den Tätigkeitsdelikten", Christian Fahl u. a. (Hg.), Festschrift für Werner Beulke zum 70. Geburtstag, 2015, s. 327 vd.

31 Uğur Alacakaptan, Suçun Unsurları, 2. Bası, Sevinç Matbaası, 1975, s. 45. Her suçta bir neticenin olduğuna ve bu suçların neticesi harekete bitişik suçlar olarak tanımlanması gerektiğine ilişkin görüşler için bkz. Demirbaş, s. 242; Nurullah Kunter, Suçun Maddi Unsurlar1 Nazariyesi, İstanbul Üniversitesi Hukuk Fakültesi Yayınları, 1954, s. 85 vd. 
Görüldüğü üzere doğal anlamda netice kavramının daha esnek bir şekilde yorumlanıp genişletilmesiyle, her suçun muhakkak bir neticesinin olduğu görüşü ileri sürülmektedir. Ancak bu da ceza hukuku dogmatiğinin amaçları açısından başka bir soruyu beraberinde getirmektedir. Her suçta bir neticenin olduğu görüşü anlamlı bir sınıflama ortaya çıkarabilmekte midir? $\mathrm{Bu}$ soruya olumsuz cevap verilmelidir! Bugün için ceza hukuku dogmatiği açısından anlamlı bir netice kavramı vardır; o da neticenin dar anlamda doğal netice anlayışına dayanmaktadır. Dar anlamda netice de yine doktrindeki hâkim görüş tarafından vurgulandığı üzere sadece illiyet bağı açısından sorun yaratmaktadır. ${ }^{32}$ Ayrıca belirtilmelidir ki sırf hareket suçu ile neticeli suç ayrımının pratik bakımdan önemi, kendisini zamanaşımı, suçun işlendiği yer ve teşebbüs gibi ceza hukuku kurumları bakımından da göstermektedir. Örneğin sırf hareket suçlarında hareket yapılır yapılmaz suç tamamlandığında zamanaşımı o andan itibaren işleyecektir. Yine bu suçlar hareketin yapıldığ 1 yerde gerçekleştirilmiş ve bu aşamada tamamlanmış sayılır. ${ }^{33}$ Bütün bu eleştirilere ayrıca neticenin harekete bitişik olduğu iddiasının, ontolojik olarak tanımlanamayan tipiklik öğretisinin verilerine aykırı faraziye bir iddia olduğunu da eklemek mümkündür. Örneğin, hakaret ve giyapta hakaret suçunda harekete bitişik nasıl bir neticenin olduğu hususu izaha muhtaçtır. Eğer yalan tanıklık suçunda olduğu gibi netice mağdurun duyması olarak tanımlanacaksa, gıyabi hakarette suçun faili veya müşterek faili bunu mağdura ileten kişi mi olacaktır? Cumhurbaşkanına hakaret suçunda işlenen suçtan çoğunlukla Cumhurbaşkanının haberi dahi olmamaktadır. Kamu makamları re'sen devreye girmekte ve suçu Adalet Bakanının izni ile soruşturmaktadır (TCK m. 299). Hukukta olan, gösterilebilir olmalıdır. Bu bağlamda esasen neticenin muhakkak bulunduğu ve bunun en azından harekete bitişik olduğu iddiasının, ${ }^{34}$ neticeden hukuki değerin ihlalinin anlaşılması fikriyle temellendirilmesi gerekmektedir. Ayrıca her suçun bir neticesinin olduğu fikri tipiklik öğretisinin dışında tanımlanacak ve anlamlandırılacak olursa bizatihi hareketin kendisinin bir netice olduğunu söylemek, hareketin failin iradesinin bir sonucu olması açısından anlamlıdır/mümkündür. ${ }^{35}$

Bütün bu bilimsel veriler neticeli suçların pratik hukuk açısından gösterdiği önem açısından anlamsızdır. Çünkü netice ceza hukukunda

\footnotetext{
32 Rönnau, s. 962. Aksi yöndeki görüşler için bkz. Kunter, s. 85.

33 Artuk / Gökcen / Yenidünya, s. 252; Demirbaş, s. 242.

34 Kunter, s. 85.

35 Jescheck / Weigend, s. 260.
}

442 Ankara Hacı Bayram Veli Üniversitesi Hukuk Fakültesi Dergisi C. XXV, Y. 2021, Sa. 2 
zamanaşımı, suçun işlendiği yer, iştirak gibi çeşitli pratik uygulamalar açısından anlamını korumaktadır. Ayrıca sırf hareket suçu ile neticeli suçlar arasındaki ayrım reddedildiğinde bu konulara ilişkin dogmatik tartışma fikriyatı ve bahsedilen konulardaki uygulamalar zarar görecek ve kimi hukuki belirlilikler ortadan kalkacaktır.

Neticeli suçlar ile sırf hareket suçlarının incelendiği çalışmanın bu bölümünde küçük bir parantezin kalkışma/girişim/teşebbüs ${ }^{36}$ suçları açısından açılması gerekmektedir. Bu suçlarının en önemli özelliği, suç tipinde suça teşebbüs ile suçun tamamlanmasının aynı ana işaret etmesidir. Suç, teşebbüs edildiğinde tamamlanmış olur. Özel hükümlerdeki kanun metninin "girişim" (unternehmen/kalkışma) kavramını kullandığı suç tipleri gerçek anlamda kalkışma suçu olarak tanımlanmaktadır. Bir suça teşebbüs ile hareketin tamamlanmasının aynı derecede cezalandırıldığ 1 ve bunun hareketin

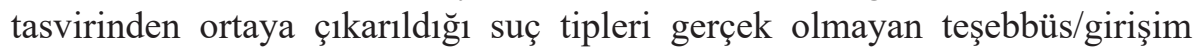
suçları olarak tanımlanmaktadır. Bu konuda Alman hukukunda verilen tipik örnek, AlCK'nin 292. maddesinde düzenlenmiş olan kaçak avlanma suçunda "av hayvanlarının izlenmesi" (dem wilde nachstellen) fiilidir. ${ }^{37}$ Bizim hukukumuzda ise 5237 sayılı TCK'nın "Millete ve Devlete Karşı Suçlar ve Son Hükümler” başlıklı dördüncü kısım, "Anayasal Düzene ve Bu Düzenin İşleyişine Karşı Suçlar" beşinci bölüm başlığı altında düzenlenen "Anayasay1 ihlal" suçu (TCK m. 309) kalkışma suçlarına örnek olarak gösterilebilir. Kalkışma suçlarının esasen pratik önemi kendisini teşebbüsten dolayı bir ceza indiriminin ortadan kaldırılmasında göstermektedir. ${ }^{38}$

\section{Zarar ve Tehlike Suçları Ayrımının Anlamı}

Neticenin formel ve dar anlamda anlaşılması düşüncesi zaman içerisinde daha da geliştirilerek suç tipleri açısından farklı bir ayrım ortaya çıkarılmıştır. Bu ayrımın temel özelliği, kendisini hukuki değer merkezli daha muhteviyat ile ilgili bir analize yöneltmiş olmasıdır. Buna göre suç; hareketin hukuki değerin korumaya aldığı obje ve konu (rechtsgutobjekt/schutzobjekt) üzerinden yapılmalıdır ve bu koruma objesi ile fiilin üzerinde gerçekleştiği veyahut saldırının yöneldiği obje ve konular herzaman aynı şeye işaret etmemektedir.

\footnotetext{
36 Bu suçların girişim suçu olarak da çevrilmesi açısından bkz. Feridun Yenisey / Gottfried Plagemann, Alman Ceza Kanunu Strafgesetzbuch, Beta Yayınevi, İstanbul 2009, s. 13.

37 Rönnau, s. 962.

38 Claus Roxin, Strafrecht Allgemeiner Teil Band II, 4. Bas1, C.H.Beck, 2006, s. 445, kn. 345; Jescheck / Weigend, s. 267.
} 
Buna göre suçlar koruma objesi üzerindeki etkisine göre soyut tehlike, somut tehlike veya zarar suçu olarak nitelendirilmektedir. ${ }^{39}$ Ancak ceza hukuku doktrini açısından görece yeni olan bu iddia, yapısal olarak bazı farklılıklar gözetmekte ve özellikle uygulama açısından soyut ve somut tehlike suçu arasındaki farklar büyük önem taşımaktadır. ${ }^{40}$ Söz konusu iddiadaki yeni noktayı incelemeye geçmeden önce, bu başlık altında da kimi bilinen hususlar tekrar gözden geçirilmelidir.

\section{A. Zarar ve Tehlike Suçları Ayrımı İçin 'Suçun Maddi Konusu' veya 'Geleneksel Suçun Konusu' Elverişli Bir Ölçüt müdür?}

Türk öğretisinde zarar ve tehlike suçları arasındaki ayrımın esasen suçun maddi konusu veya suçun konusu kavramlarının fiilden etkileniş derecesine göre yapıldığı görülmektedir.

1) 'Suçun maddi konusu' görüşü: Türk hukukunda kimi yazarlar zarar ve tehlike suçu arasındaki ayrımı suçun maddi konusu üzerinden yapmaktadırlar. Bu yazarlardan;

Dönmezer/Erman, suçun konusunu hukuki ve maddi anlamda ikiye ayırdıktan sonra, maddi bakımdan suçun konusunu suçun cismini teşkil eden insan ve şey olarak belirlemiştir. ${ }^{41}$

Hafizoğullarl/Özen'e göre suçun maddi konusu, suçun maddeten etkilerini üzerinde gösterdiği varlıktır. Bu varlık, bir kimse olabileceği gibi bir şey de olabilir. ${ }^{42}$ Yazarlar zarar ve tehlike suçunu hukuki değerlerin zarar ve tehlikeye uğraması açısından zarar ve tehlike suçu olarak ikiye ayırmaktadır. ${ }^{43}$

Soyaslan'a göre suçun maddi konusu suçu teşkil eden unsur olup yapısı itibariyle şahıs veya eşyadan ibarettir. ${ }^{44}$ Yazar zarar ve tehlike suçlarını birer netice olarak kabul edip hukuki değere verilen zarar ve tehlike olarak tanımlamaktadır. ${ }^{45}$

\footnotetext{
Rönnau, s. 962.

40 Johannes Wessels / Michael Hettinger, Strafrecht Besonderer Teil, C. I, 29. Bas1, C.F. Müller, 2005, s. 277, kn. 949, 950.

41 Dönmezer/Erman, s. 333.

42 Hafizoğulları / Özen, s. 232.

43 Hafizoğulları / Özen, s. 75, 229.

44 Soyaslan, s.305.

45 Soyaslan, s.260.
}

444 Ankara Hacı Bayram Veli Üniversitesi Hukuk Fakültesi Dergisi C. XXV, Y. 2021, Sa. 2 
Toroslu, suçun maddi konusunu tipik fiilin üzerinde gerçekleştirilmesi zorunlu olan şahıs veya şey olarak tanımlamaktadır. Yazara göre suçun maddi konusu sadece maddi ve fizik varlığa sahip olan varlıklar olabilir. ${ }^{46}$ Yazar her ne kadar zarar ve tehlike suçları arasındaki ayrımı hukuki değerin ihlali esasına dayandırmış olsa da söz konusu ayrımın maddi konuları ihlal edilen suçlarda güvenilir olabileceğini belirtmektedir. ${ }^{47}$

Önder, hareketin yönelmiş olduğu konu ve suç tipinde belirtilmiş olan konunun genelde maddi bir bünyesi olan bir konu olduğunu bir şey insan veya eşya olması gerektiğini belirttikten sonra maddi konusu olmayan suçlarda hukuki yararın bu suçların konusunu oluşturduğu görüşündedir. ${ }^{48}$ Yazar suç tipinde belirtilen hareketin yönelik olduğu konunun hareketten etkileniş derecesine ve şekline göre suçları zarar suçu ve tehlike suçu olarak ikiye ayırmıştır. ${ }^{49}$

Ünver ise suçun maddi konusunu suçun objektif unsuru olarak tanımlayıp suça vücut veren hareketin suçun maddi konusu olan obje ve şahıs üzerinde icra edileceğini belirtmektedir. ${ }^{50}$ Yazara göre maddi konu, failin fiziki hareketine maruz kalan, eylem üzerinde inşa edilen kişi veya eşyadır. ${ }^{51}$ Ancak yazara göre zarar ve tehlike bir hukuksal değerin ihlal edilmesidir. ${ }^{52}$

Zafer ise yine suçun maddi konusu üzerinden bir tanımlama yolunu seçmiştir. Yazara göre suçun maddi konusu fiilin üzerinde gerçekleştiği, kişi eşya veya hayvandır. Cismi olmayan şeyler suçun maddi konusunu oluşturamaz, bunlar suçun hukuki konusunu oluşturur. Suçun maddi konusunun zarar görmesine veya zarar görme ihtimaline göre suçlar zarar ve somut tehlike suçları olarak ikiye ayrılmaktadır. ${ }^{53}$

2) Geleneksel 'Suçun Konusu' görüşü: Türk hukukunda kimi yazarlar ise suçun maddi konusu görüşünü reddetmekte ve her suçun maddi konusu

\footnotetext{
46 Toroslu /Toroslu, s. 110.

47 Toroslu / Toroslu, s. 110.

48 Ayhan Önder, Ceza Hukuku Dersleri, 1. Bası, Filiz Kitabevi, 1992, s. 169, 170.

49 Önder, s. 175.

50 Yener Ünver, Ceza Hukukuyla Korunması Amaçlanan Hukuksal Değer, Seçkin Yayınevi, 2003, s.142.

51 Ünver, s.145.

52 Ünver, s.1062.

53 Hamide Zafer, Ceza Hukuku Genel Hükümler, 4. Bası, Beta Basımevi, 2015, s. 162, 163.
} 
kavramının olmayacağı, suçun konusu kavramının kullanılmasının esasen daha doğru olduğu görüşündedirler. Bu yazarlardan;

Özgenç, suçun konusunun eşya veya şahsın fiziki, maddi yapısı ve bünyesi olduğu görüşündedir. Yazar; suçun konusu kavramının hukuki değer ile karıştırılmaması gerektiği, suç konusunun maddi unsurlardan birini oluşturduğu, öldürme suçlarında korunan hukuki değerin yaşam hakk1 olduğunu suç konusunun ise belli bir kişinin hayatı olduğu görüşündedir. Yazar şeref kavramını da suçun konusu içerisinde şerh ederek hakaret suçlarında korunan hukuki değerin genel olarak kişilerin şerefli, onurlu ve saygın olması olduğunu belirttikten sonra hakaret suçunun konusunun hakaret edilen kişinin şerefi olduğunu savunmaktadır. Bu yönüyle yazar esasen fiziki varlığı olmayan varlıkların da suçun konusu olabileceği görüşündedir. ${ }^{54}$ Yazar zarar ve tehlike suçları arasındaki ayrımını da suçun konusu üzerinden yapmakta ve işlenen fiilin suçun konusu üzerindeki etkisine göre suçlar zarar ve tehlike suçları olarak ikiye ayrılmaktadır. ${ }^{55}$

Koca/Üzülmez göre suçun (hareketin) mutlaka bir konusu vardır. Yazarlar konusuz bir suçun oluşmayacağını belirttikten sonra hareketin ve suçun konusunu tipik hareketin üzerinde icra edildiği kişi ve şey olarak anlamaktadırlar. ${ }^{56}$ Yazarlar hareketin konusunun hareketten etkileniş derecesine göre suçları zarar suçu ve tehlike suçu olarak ikiye ayırmaktadırlar. ${ }^{57}$

Öztürk/Erdem'e göre, suçun konusu fiilin nesnesini oluşturan ve tipik varlığın üzerinde gerçekleştiği maddi varlığı olan şey olarak tanımlanmaktadır. Konusuz suçlar olabilir. ${ }^{58}$ Suçlar zarar ve tehlike olarak suç konusu üzerindeki etkiye göre ayrılmaktadır. ${ }^{59}$

Akbulut ise suçun konusunu hareket ve hareketin yönelik olduğu eşyanın ve kişinin fiziki varlığı olarak tanımladıktan sonra; suçun konusunda kural olarak maddi varlığa sahip varlıklar ifade edilmek ile beraber sır, şeref, veri

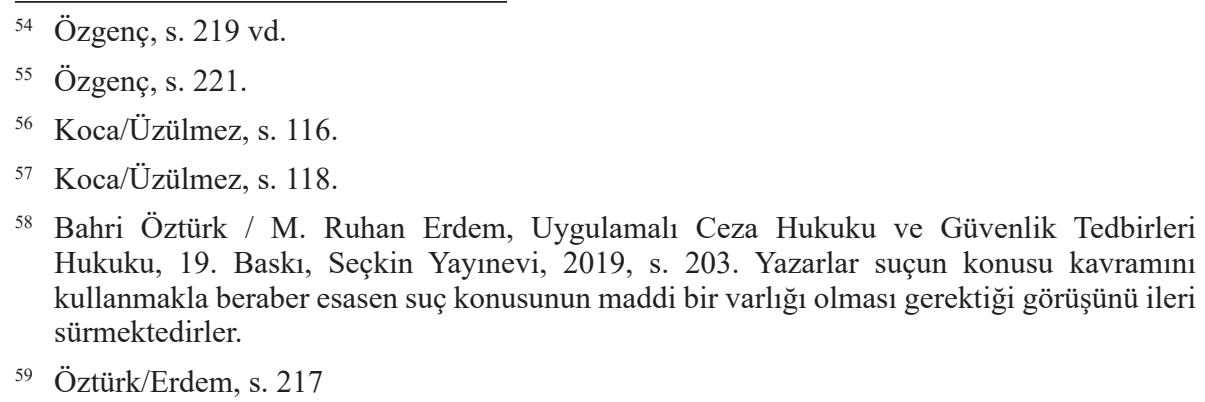


gibi maddi bünyeye sahip olmayan şeylerin de haksızlığın konusu olabileceğini vurgulamış ve yine zarar ve tehlike suçları arasındaki ayrımı suçun konusunun hareketten etkileniş şekline göre yapmıştır. ${ }^{60}$

Artuk/Gökçen/Yenidünya ise suçun konusunu hareketin yöneldiği kişi veya şey olarak tanımlamakta, konusuz suçun olamayacağı görüşünü ileri sürdükten sonra suçları suç konusunun hareketten etkileniş derecesine göre zarar ve tehlike suçları olarak ikiye ayırmaktadır. ${ }^{61}$

Centel/Zafer/Çakmut ise suçun konusunu suçun üzerinde işlendiği insan veya obje olarak tanımlamaktadır. ${ }^{62}$ Aynı yazarlar zarar ve tehlike suçu arasındaki ayrımı ise suçun neticesi üzerinden yapmakta, hukuki yararın zarar ve tehlikeye uğraması durumunu zarar ve tehlike suçu olarak tanımlamaktadırlar. ${ }^{63}$

3) Suçun Konusuna İlişkin Yeni bir Tanım Denemesi 'Hukuki Değerin İlişkili Olduğu Konu olarak 'Suçun Konusu”

Yukarıdaki görüşlerden de anlaşılacağ maddi konusu ile suçun/hareketin konusunun maddi bir varlığının olup olmaması üzerinde toplanmaktadır. Tartışmayı suçun maddi unsuru üzerinden yürüten yazarlar esasen suçun üzerinde gerçekleştiği konunun cismani bir varlığının olması gerektiği görüşündedirler. Nihayetinde her suçta 'maddi bir konu' olmayacağını tespit ederek zarar ve tehlike suçunu hukuki değerin zarar ve tehlikeye uğraması olarak tanımlamaktadırlar. Buna karşılık, 'suçun konusu' terimini kullanan yazarlar ise her suçun muhakkak bir konusu olması gerektiği görüşünü savunduktan sonra cismani bir varlık olmasa da şeref gibi varlıkların da suçun konusu olduğu görüşünü savunmaktalardırlar. Her iki gruptaki yazarlar suçun (maddi) konusu ile suçla ihlal edilen hukuki değeri kategorik olarak ayırmakta ancak yazarların büyük çoğunluğu zarar ve tehlike suçları arasındaki ayrımı hareketin gerçekleştiği suçun konusu üzerindeki etkiye göre gruplamaktalardırlar.

Arz edilen her iki görüşün de ortak özelliği, fiilen saldırı yapılan objeyi objenin (Tatobjekt) maddi veya manevi olmasına bakmaksızın esas almalarıdır.

\footnotetext{
60 Akbulut, s. 425-427

61 Artuk / Gökcen / Yenidünya, s. 304-305.

62 Nur Centel/Hamide Zafer/Özlem Yenerer Cakmut, Türk Ceza Hukukuna Giriş, 11. Bask1, Beta Yayınevi, 2020, s. 236.

${ }^{63}$ Centel/Zafer/Çakmut, s. 270.
} 
Fiilen hareketin yöneldiği obje üzerinden bir tanımlama yapılmaktadır.

Zarar/tehlike suçları arasındaki bu hâkim yaklaşım, yani hareketin fiilen yöneldiği suçun konusu (tatobjekt/maddi olsun olmasın) üzerinden yapılan analiz, geleneksel Alman doktrinine de uygun bir yaklaşımdır. Nitekim Alman hukukunda zarar ve tehlike suçları arasındaki ayrım konusunda, suçun konusunun zarar veya tehlikeye düşürülmüş olması ve bu tehlikenin somut olup olmamas1 temel kistas kabul edilmektedir. ${ }^{64}$

Görüldüğü üzere geleneksel hukuk doktrini açısından kabul edilen modellemede suçlar öncelikle neticeli ve neticesiz suçlar olarak ikiye ayrılmakta ve neticesiz suçlar sırf hareket suçu kabul edilmektedir. Sırf hareket suçlarında kanunda öngörülen hareketin icrası ile suç gerçekleşmektedir. Öte yandan suçun konusu üzerindeki etkisi esas alındığında suçlar öncelikle zarar suçu ve tehlike suçu olarak ikiye ayrılmaktadır. Tehlike suçları ise kendi içerisinde soyut tehlike ve somut tehlike suçu olarak ikiye ayrılmaktadır. Somut tehlike suçlarında kanunda gösterilen hareketin tipiklikte gösterilen bir tehlikeye yol açması gerekli iken soyut hareket suçlarında ise hareketin icrası ile suçun gerçekleşmiş olduğu belirtilmektedir. Buradan hareketle sırf hareket suçları ve soyut tehlike suçları bir arada değerlendirilerek her sırf hareket suçunun bir soyut tehlike suçu olduğu veyahut her soyut tehlike suçunun bir sırf hareket suçu olduğunu söylemek mümkündür. Nitekim doktrinde birçok yazar bu görüşü savunmaktadır. ${ }^{65}$

Ancak ister suçun maddi konusu isterse geleneksel suçun konusu kavramı tercih edilsin zarar ve tehlike suçları arasındaki ayrımın hareketin fiilen yöneldiği (tatobjekt) şahıs ve şey üzerinden yapılması hususu kendi içerisinde tutarsızlıklar yaratabilmektedir. Her ne kadar yukarıda verilen örnekler üzerinden yapılan değerlendirmede klasik suçlar ele alındığı için belli bir tutarlılığa ulaşılmış olsa da suçun konusu konusundaki geleneksel görüş de aslında suçun maddi konusunda olduğu gibi hareketin fiilen yöneldiği fiilen gerçekleştiği değer üzerinden yapılmaktadır. Dolayısı ile ister maddi konu ister suçun konusu görüşü ele alınsın fiili saldırının gerçekleştiği obje üzerinden yapılan bu ayrım bütün suç tiplerini kapsayıcı bir şekilde bir çözüme ulaşmaya imkân tanımamaktadır. Şöyle ki;

64 Jescheck / Weigend, s. 263, 264; Roxin, C. I, s. 337, kn. 123-124; Otto, s. 41, kn. 11.

65 Bkz. Artuk / Gökçen / Yenidünya, s. 287; Akbulut, s. 311; Jescheck / Weigend, s. 264, Uğur Ersoy, "Ceza Hukukunun Gri Alanı: Tehlike Suçları", 2020, 41, Y. 11, TAAD, s. 46. Öztürk/ Erdem, s. 219. 
a) Öncelikle suçun konusunun muhakkak maddi olması gerektiğine ilişkin görüşler açısından vurgulanmalıdır ki birçok suç tipinde suçun maddi bir konusu bulunmamaktadır. Bu bağlamda temel kimi kabulleri yeniden hatırlamak gerekir. Kanuni tipin çekirdeği niteliğindeki hukuki değer; ${ }^{66}$ suç ile ihlal edilen, ceza tehdidi ile korunma altına alınmış hukuki değer veya menfaat olarak tanımlanmaktadır. ${ }^{67}$ Suç ile ihlal edilen hukuki değer ile suçun maddi konusu kavramı karıştırılmamalıdır. ${ }^{68}$ Hukuki değer; maddi değil, soyut olarak kavranabilir bir yapıdadır. ${ }^{69}$ Suçun maddi konusu ise yukarıdaki kimi yazarlarca belirtildiği üzere fiilin nesnesini oluşturan ve tipik davranışın üzerinde gerçekleştiği ve maddi varlığ 1 olan şey olarak tanımlanmaktadır. ${ }^{70}$ Cismi olmayan şeyler suçun maddi konusunu oluşturmaz. ${ }^{71}$ Örneğin; kasten veya taksirle yaralama suçunda suçun hukuki konusu kişinin vücut bütünlüğü iken suçun konusu ise kişinin vücudu olarak karşımıza çıkmaktadır. ${ }^{72}$ Suç ile ihlal edilen hukuki değer ile suçun (maddi) konusu arasındaki ayrım konusunda doktrinde büyük ölçüde fikir birliği olduğu gözlemlenmektedir. ${ }^{73}$ Ancak bu açıklamalar, yalnızca maddi konu ile hukuki değerin bir arada ve yakın bir ilişkide bulunduğu suç tipleri için kolaylıkla yapılabilmektedir. ${ }^{74}$

Suçun maddi konusu görüşünden hareket edildiğinde maddi konusu olmayan suçlar bakımından açıklama yapma zorluğuna düşülmektedir. ${ }^{75}$ Çünkü bu tür suçlarda esasen fiilin üzerinde gerçekleştiği “maddi bir görünüm

66 Ünver, s. 109.

67 Hafızoğulları / Özen, s. 199. Ceza hukukunun sınırlanmasında hukuki konu kavramının anlam ve önemi için bkz. Elvan Keçelioğlu, "Risk Toplumunda Ceza Hukukunun Değişen Yüzü”, Prof. Dr. Nevzat Toroslu'ya Armağan, C. 1, Ankara Üniversitesi Yayınları, 2015, s. 632.

68 Toroslu, Hukuki Konu, s.193 vd.

69 Ünver, s. 534; Toroslu, Hukuki Konu, s. 196.

70 Öztürk / Erdem, s. 202. Ayrıca yukarıda suçun maddi konusu kavramını kullanan yazarlar için bkz. bölüm başlığı: II. A. 1.

71 Zafer, s. 163

72 Özgenç, s. 219, 220; Öztürk / Erdem, s. 202., Jescheck / Weigend, s. 256 vd. Koca/Üzülmez, s. 117 vd., Zafer, s. 154, Roxin, C. I, s. 33, kn. 65.

73 Özgenç, s. 219, 220; Öztürk / Erdem, s. 202.

74 Örneğin yaralama suçlarında maddi konu vücut iken hukuki konu vücut dokunulmazlığıdır. Benzer şekilde hırsızlık suçunda maddi konu bir eşya iken hukuki konu mülkiyet/zilyetlik olarak karşımıza çıkmaktadır. Stratenwerth / Kuhlen, s. 76.

75 Zafer, s.163. Bu bağlamda Trafik Güvenliğini Tehlikeye Düşürme Suçu öğretide konusuz suçlara örnek olarak gösterilmektedir. Öztürk/Erdem, s. 194. 
formu" bulunmamaktadır. Örneğin TCK'nın 292. maddesinde düzenlenen hükümlü veya tutuklunun kaçması suçunda, korunan hukuki değer adil ve güvenli bir toplumda yaşama hakkı iken korunan hukuki değerin ilişkili olduğu konu kişilerin güvenliğidir. Ancak bu suçta suçun maddi konusu bulunmamaktadır. ${ }^{76}$ Yine aynı şekilde TCK'nın 294. maddesinde düzenlenen kaçmaya imkân sağlama suçunda da herhangi bir maddi konu bulunmaz iken korunan hukuki değer adil ve güvenli bir toplumda yaşama hakkı ile ilişkili olan kişi güvenliğidir. Dolayısı ile zarara uğratılan ve tehlikeye düşürülen bir maddi konunun bulunmadığı bu tür suçlar zarar ve tehlike suçu ayrımına elverişli değildir. Maddi konu kriteri bu bağlamda işlevsel değildir.

Yukarıda gösterildiği üzere; maddi konusu olmayan suçlar bakımından, suçun maddi konusunun yanı sıra kimi sosyal değerler de suçun konusu içerisinde değerlendirilmekte ve suçun hukuki konusu olarak nitelenebilecek kimi değerler suçun konusu haline getirilerek içeriği doldurulmaya çalışılmaktadır. ${ }^{77}$ Aynı şekilde özel hayatın gizliliğini koruyan ve cebir kullanma gibi insanın özgür iradesini etkileyen suçlarda, esasen fiilin üzerine fiilen yöneldiği maddi bir yapı bulunmamaktadır. Dolayısı ile böylesi suç tiplerinde suçun maddi konusundan bahsetmenin bir anlamı da bulunmamaktadır. Ancak anılan durumlarda hukuki konunun somut durumdan soyutlanarak tanımlanması kimi karışıklıklara yol açmaktadır. Bu durumlarda telifçi bir yaklaşımla suçun maddi konusu kavramından feragat edilerek suçun konusu kavramı kullanılmaya başlanmaktadır. Maddi bir varlığı bulunmayan durumlar örneğin esasen şeref gibi hakaret suçlarında suçun konusu olarak gösterilen ancak vücutsal bir yapı ortaya koyamayan değerlerden bahsedilirken anlatılan şey suç ile ihlal edilen değerden başka bir şey değildir. ${ }^{78}$ Bütün bu durumlarda da suçun maddi konusu veya konusu kavramı kendi anlamını kaybetmektedir.

b) Üzerinde durulması gereken ikinci nokta ise hareketin fiilen üzerine yöneldiği şahıs veya şey olarak maddi konu veya geleneksel anlamda suçun konusu ile hukuki değerin veya konunun fiilen koruma altına aldığı konunun birbirinden farklı olması durumudur. Yani hukuki konunun koruma altına aldığı obje ile addi konunun aynı olmaması durumudur. Bu durumda zarar suçu ve tehlike suçu ayrımı nasıl yapılacaktır? Geleneksel öğretiye uygun bir

76 Erdin, s. 44, dn. 213.

77 Suçun maddi konusunun sosyal değerler görünümü bilgisi için bkz. Jescheck / Weigend, s. 260. Hakaret suçlarında şeref kavramının suçun konusunu oluşturduğu yönündeki görüş için bkz. Artuk / Gökcen / Yenidünya, s. 285.

78 Stratenwerth / Kuhlen, s. 76. 
şekilde suçun maddi konusu tespit edilecek ve onun zarara veya tehlikeye uğraması olarak sorun çözülecek olursa amaca uygun bir çözümlemeye ulaşlabilecek midir?

Görüldüğü üzere zarar ve tehlike suçlarının, hareketin suçun (maddi) konusu üzerindeki etkisine göre değil, hukuki konunun objesi üzerindeki etkisine göre sınıflandırılması geleneksel yaklaşımdan bir sapma özelliği göstermektedir. ${ }^{79}$ Öncelikle belirtilmelidir ki suçun maddi konusu ile hukuki konunun objesi, ceza hukuku çalışmalarının üzerinde yoğunlaştığı geleneksel suç tipleri açısından (öldürme, yaralama, malvarlı̆̆ 1 aleyhine işlenen suçlar vs) aynı şeye işaret etmektedir.

Bu bağlamda vurgulanmalıdır ki Alman hukukunda esasen zarar suçları ile neticeli suçlar arasındaki ilişki sorgulanır iken bazı zarar suçlarında kanunda gösterilen tipik neticenin gerçekleştirilmesine ve suçun maddi konusu (einwirkungsobjekt) üzerinde etki meydana getirilmesine rağmen suç tipiyle koruma altına alınmış/hukuki değer ile ilişkilendirilmiş objenin zarar uğratılmadığ 1 tespit edilmiştir. Buna örnek olarak ise belgede sahtecilik suçlarında sahte belge düzenleme alternatif seçimlik hareketi verilmektedir.

79 Türk hukukunda suçun konusu ile ilgili çalışmalarda suçun maddi konusu, suçun konusu ve hukuki konunun konusu gibi kimi kavramların farklılığı üzerinde belli bir farkındalık olușmuș ancak bunların aynı anlamda kullanıldığı görüşleri ileri sürülmüștür. $\mathrm{Bu}$ görüşlerden Bulut'a göre; "Suçun maddi unsurlarından biri olan "konu", doktrinde çeşitli şekillerde tanımlanmaktadır. Suçun konusu, "suçun üzerinde meydana geldiği șey", "suçun cismini teşkil eden insan veya şey", "suç failinin hareketinin yöneldiği kişi ya da şey", "eşya veya şahsın fiziki, maddi yapısı" vb. şekillerde tarif edilmektedir. Doktrinde bizim suçun konusu olarak ifade ettiğimiz kavram "hareketin konusu", "hukukî değerin konusu", "ihlalin konusu" gibi başka pek çok terimle ifade edilmektedir." İlhan Bulut, Suçta Netice, Yıldırım Beyazıt Üniversitesi Sosyal Bilimler Enstitüsü Yayınlanmamış Doktora Tezi, 2020, s. 144. Yine yeni tarihli bir çalışmada Ünal; "Doktrinde "hukuki değer objesi" ("Rechtsgutsobjekt") ile ifade edilen terim, suçun kanuni unsurunda bulunan konu (obje) ile aynı anlama gelmektedir. Bundan başka doktrinde "hareket objesi" ("Handlungsobjekt"), "saldırı objesi" ("Angriffsobjekt"), "fiil objesi" ("Tatobjekt") kavramlarına da rastlamaktayı. Bu kavramlar da eş anlamlı olarak kullanılmaktadır. Yani karşımıza çıkan bu kavramlar maddi unsur altında yer alan suçun konusundan başka bir şey değildirler. Hukuki değeri hukuki konu olarak ele alan görüşler suçun konusunu maddi konu olarak adlandırmışlardır. Buna göre suçun cismini oluşturan insan veya şey suçun maddi konusudur. Dikkat çeken bir diğer kavram olan "koruma objesi" ("Schutzobjekt") kavramı hukuki değer kavramıla eş anlamlı olarak kullanılmaktadır. Normun koruduğu şeyin ancak hukuki değer olduğundan hareketle koruma objesiyle aynı anlama geldiği belirtilse de suçun konusu kavramı ile ayrımının zaten birtakım güçlüklerle karșılașıldığı göz önüne alındığında koruma objesi kavramının kullanımının doğru olmadığını gözlemlemekteyiz" diyerek kavramlar arasında bir fark görmemektedir. Bkz. Osman Gazi Ünal, Türk Ceza Hukuku'nda Tehlike Suçları, Yayımlanmamış Doktora Tezi, Ankara Hacı Bayram Veli Üniversitesi Lisansüstü Eğitim Enstitüsü, 2020, s. 135. 
Sahte belgenin düzenlenmesi ile kanunda gösterilen tipik neticenin gerçekleştiği ancak bizatihi bu belge korunan obje olmadığ için bu belgenin zarara uğramasının gerekmediği, zarara ve tehlikeye uğrayanın bu obje olmadığı bilgisine ulaşılmıştır. ${ }^{80}$

Nihayetinde yine Alman hukukunda bu kavramları birbirinden ayırmaya yönelik tanım denemeleri yapılmaya başlanmıştır ve hukuki değer ile koruma altına alınmış menfaati temsil eden nesne (rechtsgutobjekt) kavramı ortaya atılmıştır. Yukarıda da ayrıntıları ile belirtildiği üzere öğretide suçun maddi konusu ile suçun konusu arasındaki ayrımın hareketin fiilen yöneldiği değerin maddi ve manevi değerler olması açısından yapılan bir ayrıma dayandırıldığı söylemiştir. Bu bağlamda suçun konusu kavramının başka yönlerden de suçun maddi konusu kavramından ayrılabilir bir tanım yapılması zarureti doğmaktadır. Bu bağlamda hukukumuzda suçun konusu kavramı tanımlanırken Alman hukukunda hukuki değerin konusu olarak çevrilebilecek 'rechtsgutsobjekt' kavramına verilen anlamların, suçun konusu kavramına da yüklenmesi gerekmektedir. Buna göre esasen suçun konusu "rechtsgutsobjekt" kavramını da içerir bir şekilde tanımlanacak olursa bu somut bir objedir. $\mathrm{Bu}$ obje hukuki değer açısından koruma altına alınmış ve korunan hukuki değere uygun davranılması talebi bu objeye özen gösterilmesine bağlanmıştır. $\mathrm{Bu}$ obje esasen zarar ve tehlikeye uğratılabilir. Bu bağlamda bir insanın yaşamı, bir başkasına ait olan eşya, değiştirilmesi hukuken mümkün olmayan para buna örnek olarak gösterilmektedir. ${ }^{81}$ Hukuki konunun objesi kavramı somut bir olayda somut bir obje üzerinden hukuki değerlere uygun davranılması talebiyle doğmaktadır.

Buna karş1lık suçun maddi konusu (Tatobjekt/hareketin objesi) hukuki değerin korumaya aldığı bir objeden söz edilmeksizin somut hareketin yöneldiği, üzerinde gerçekleştiği bir insan veya şey olabilir. Örneğin memuriyet görevini yaparken saldırıya uğrayan bir memur esasen suçun maddi konusunu oluşturmaktadır. Ancak bu memur görevinin yerine getirilmesi engellenmek için zarar uğratılıyor ise bu memur esasen hukuki değerin objesi olmaktadır. ${ }^{82}$

\footnotetext{
${ }^{80}$ Günther Jakobs, Strafrecht Allgemeiner Teil, 1. Bas1, DeGruyter, Berlin 1983, s. 142, Goeckenjan, s. 50. Ancak Alman doktrininde Roxin, bu ayrımı yapmamaktadır. Roxin, s. 337, kn.123. Aynı şekilde Wessels/Beulke/Setzger de bu yönlü bir ayrım yapmamaktadır. Johannes Wessels / Werner Beulke / Helmut Setzger, Strafrecht Alllgemeiner Teil, 45. Bas1, C.F. Müller, 2015, s. 12, kn. 40.

81 Eberhard Schmidhäuser, Strafrecht Allgemeiner Teil, 2. Bas1, Mohr Verlag, 1975, s. 37-38.

82 Schmidhäuser, s. 37-38.
} 
Hareketin objesi hareketin dış görünüşü ile ilgilenirken koruma objesi ise norm kavramı tarafinda var olmaktadır. Bunun sonucu olarak hareketin objesi suçun kanuni tarifinde tanımlanmışken korunan hukuki değer ise bu tarifin dışında yer almaktadır ${ }^{83}$ Hareketin yöneldiği obje, fiilin gerçekleştirildiği objedir ve suçun konusu olan ve hukuki değerin somut olayda koruma altına aldığ1 suçun konusu ile aynı olmak zorunda değildir. ${ }^{84} \mathrm{Bu}$ kavramlar çoğunlukla aynı şeye işaret etse de bazen aşağıda görüleceği üzere birbirinden farklılaşabilmektedir. Hukuki değere özen gösterilmesine bağlı talebi ("Achtungsanspruch") olarak gören ve suçun konusunu hukuki değer objesi olarak adlandıran bu düşünceye göre, bu obje hukuki değerin özen talebine yapışan somut bir objedir ve onun tarafinda varllğına zarar verilebilir veya tehlikeye düşürülebilir. Bu düşünce sadece hukuki değer ve hukuki değer objesi arasında bir ayrım yapmamakta, failin hareketinin ilişkili olduğu konuyu hareketin objesi (suçun maddi konusu veya geleneksel anlamda suçun konusu) olarak tanımlamaktadır. Dolayısıyla hukuki değer objesi ve hareketin ilişkin olduğu konu birbirinden farklıdır. Hukuki değer objesi hukuki değeri temsil eden, değerin üzerinde cisimleştiği somut bir obje iken, fiil objesi (tatobjekt/ handlunsobjekt) üzerinde icra edilen konudan ibarettir. ${ }^{85}$

Esasen bizim hukukumuzda da konuya davranış normlarının değerlendirme fonksiyonu açısından yaklaşan Özgenç; "davranış normları ile hukuki koruma altına alınan hukuki değer bir şahıs ve eşyanın ilişkin olduğu bir husustur... Hukuki değerler doğrudan zarar ve tehlikeye uğramaz... Suç bu ideal değerleri tanımama anlamına gelir ve her suç teşkil eden fiil aynı zamanda bir hukuki değerin ihlalidir... Hukuki değer ile ilişkilendirilemeyen bir suçtan bahsedilemez... Hukuki değerler kendi içerisinde derecelendirilebilir. Bu derece farkllliğl zorunluluk halinde büyük önem taşır... Zorunluluk halinde bir hukuki değerin ilişkin olduğu konu örn. bir kişinin hayatı tehlikeyle karşı karşıyadır. Bu konunun korunması uğruna daha az derecedeki bir hukuki değerin ilişkin olduğu konu feda edilmektedir (konutun kapısı kırılmaktadır.)" hukuki değerlerin ilişin olduğu bir konunun ceza hukuku dünyasında olduğunu belirtmektedir. ${ }^{86}$

\footnotetext{
83 Ünver, s. 134.

84 Rönnau, s. 962.

85 Ünal, s. 139.

86 Özgenç, s. 175-178.
}

Ankara Hacı Bayram Veli Üniversitesi Hukuk Fakültesi Dergisi C. XXV, Y. 2021, Sa. 2453 
Konuya ceza hukukun işlevi açısından yaklaşılacak olursa da aynı amaca ulaşmak mümkündür. Ceza hukukun bugün için tek amacı vardır o da esasen hukuki değerleri korumaktır. ${ }^{87}$

$\mathrm{Bu}$ değerler, hukuk tarafindan tanınan ve koruma altına alınan bireysel menfaatleri ifade etmektedir. Bunun sonucu olarak hukuksal değerler, hukuk tarafindan kendisine bir değer atfedilerek hukuki sonuç bağlanan ve hukuki koruma altına alınan bireysel menfaatler yani hukuksal formları ile haklar, özgürlükler ve benzeri hukuki kurumları ifade etmektedir. Dolayısıyla hukuksal değer kavramının temelinde zorunlu olarak kişiler ile fiziksel veya toplumsal objeler arasında var olan menfaat ilişkileri yer almaktadır. $\mathrm{Bu}$ menfaat ilişkilerine hukuk sisteminin atfettiği değer, hukuksal değer olarak karşımıza çıkmaktadır. ${ }^{88}$

Hukuksal değerlerin, hukuk sistemi tarafindan bireysel menfaatlere atfedilen değer olduğunu belirtmemiz, bu değerlerin soyut ve ideal kavramlar olarak karşımıza çıkmasına sebebiyet vermektedir. Hukuksal değerlerin hiçbir durumda maddi karşılıkları söz konusu olmadığı gibi manevi-ideal kavramlar olarak bunların zarara ya da tehlikeye uğramaları da mümkün değildir. Fail, fiilini nesnel ya da öznel, fiziksel ya da toplumsal koruma objeleri üzerinde gerçekleştirecek, bu nedenle söz konusu objeler zarara ya da tehlikeye uğratılacaktır. ${ }^{89}$ Hukuki değer bir menfaat ilişkisi olarak tanımlandığında buradaki menfaat ilişkisi tanımlaması; hukuksal değeri, menfaat ilişkisinin objesinden yani suçun konusundan (Rectsgutsobjekt) ayırmaktadır. ${ }^{90}$ Ancak burada değinilen ve hukuki değerlerin koruma altına aldığı obje ve nesne kavramları salt fiziksel değil beşeri/toplumsal gerçeklikleri de ifade etmektedir. ${ }^{91}$ Burada en temelde fiziksel varlığ 1 olan objeler söz konusu olmaktadır. Örneğin mülkiyet hakkının ilgili olduğu eşya, fiziksel bir gerçekliği ifade etmektedir. Ancak toplumsal yaşamda kişilerin yalnızca fiziksel gerçekliklerle değil, toplumsal gerçekliklerle de menfaat ilişkisi içine girmekte olduğu kuşkusuzdur. Bu bağlamda beşeri hayatta var olan 'evlilik', 'şeref', 'anayasal düzen' gibi kavramların hiçbir fiziksel karşılıkları olmadığ

\footnotetext{
87 Otto, s. 5, kn. 22.

88 Erkan Sarıtaş, Suç İşlemek İçin Örgütlenme Suçları, 1. Bası, On İki Levha Yayınları, 2018, s. 142.

89 Sarıtaş, s. 142, 143.

90 Sarıtaş, s. 142, 143.

91 Otto, s. 7 kn, s.36; Sarıtaş, s. 143.
}

454 Ankara Hacı Bayram Veli Üniversitesi Hukuk Fakültesi Dergisi C. XXV, Y. 2021, Sa. 2 
ancak bunların birer toplumsal gerçeklik olarak "var oldukları" açıktır. Kişilerin bu toplumsal gerçeklik tipleri ile menfaat ilişkileri de kaçınılmaz olarak hukuksal değerlere vücut verecektir. ${ }^{92} \mathrm{Bu}$ bakımdan hiçbir fiziksel varlığ olmayan ancak birer toplumsal varlık olan bu hususlar, hukuki değerlerin koruma altına aldığı objeler veya nesneler olarak karşımıza çıkabilecektir. Bu çerçevede koruma objesinin yani suçun konusunun hukuksal değerin ilişkili olduğu fiziki ya da toplumsal obje olduğunu söylemek yanlış olmayacaktır ${ }^{93}$

\section{Zarar ve Tehlike Suçu Ayrımında Suçun Konusuna (Hukuki Değerin Objesi Olarak) Kriterine Başvurmanın Sonuçları}

Suçun konusu (hukuki konunun objesi) ile maddi konu arasındaki farklılığın ortaya konulmasından sonra zarar ve tehlike suçları arasındaki ayrım açısından ceza hukukunda tutarlı iddialar ileri sürülebilmektedir. Çünkü bazı suçların analizinden de görüleceği üzere neticeli bir suç zarar veya somut tehlike suçu olabileceği gibi istisnai olarak soyut tehlike suçu (!) da neticeli bir suç olabilir. Örneğin Alman hukukunda, AlCK'nin 223. maddesinde düzenlenmiş bulunan "yaralama" ve $315 \mathrm{c}$ maddesinde düzenlenen "trafik güvenliğinin tehlikeye düşürülmesi" suçlarının konularının, birer zarar ve tehlike şeklinde ortaya çıkmış neticeli suçlar olduğu ifade edilmiştir. Ancak neticenin gerçekleşmesine rağmen böyle bir suç konusu bağlantısının olmadığ 1 soyut tehlike suçları da bulunabilmektedir. Anılan suçlar; tipiklikte, objektif ve sübjektif anlamda suç konusunun zarar veya somut tehlikeye düşürülmesinin öngörülmediği, hareketin gerçekleştirilmesi ile hukuki konunun tehlikeye düşürüldüğünün kabul edildiği suçlardır. $\mathrm{Bu}$ suçlara, AlCK'nin 306a maddesinde gösterilen ağır kundaklama suçu örnek olarak gösterilmektedir. Ağır kundaklama suçunun tipinde, kanun koyucu hukuki konu olarak insan yaşamının korunmasını amaç edinmektedir. İnsanların kullanımına ayrılmış binaları tamamen veya kısmen yakan kişi bu suçun failidir. Suçun maddi konusu ise binalardır. Burada binaların yanması ve zarara uğraması formel anlamda tipiklikte gösterilen neticedir. Suçun maddi konusu üzerinden analiz yapılacak olursa maddi konular yakılmış, zarara uğratılmıştır. Bu yönüyle ağır kundaklama, bir zarar suçudur. Aynı anlamda hareketten zaman ve mekân olarak bir netice meydana geldiği için neticeli bir suçtur. Ancak Alman hukukunda bu suç tipik bir soyut tehlike suçu olarak tanımlanmaktadır. ${ }^{94}$

\footnotetext{
92 Sarıtaş, s. 143.

93 Sarıtaş, s. 144.

94 Kindhäuser, s. 1179; Stratenwerth / Kuhlen, s. 76; Rönnau, s. 962; Bernd von Heintchel-
} 
Nitekim kanuni tipte insan yaşamına yönelik bir zarar veya tehlikenin ortaya çıkması aranmadığından kundaklama suçu insan yaşamının korunması açısından bir soyut tehlike suçu özelliği göstermektedir. ${ }^{95}$ Görüldüğü üzere bu tür suç tiplerinde de esasen suçun maddi konusu ile hukuki konunun objesi kavramları birbirinden farklılaşmış bir hâlde karşımıza çıkmaktadır.

Açıklanan gerekçelerle zarar suçları ile tehlike suçları arasındaki ayrımın suçun maddi konusu üzerinden yapılmaya çalışılması bizlere anlamlı bir sistematik sunmamaktadır. Zarar ve tehlikeden anlaşılması gerekenin maddi konunun üzerinde bırakılan etki olduğunun kabulü mümkün değildir. Mantıki mecburiyet icabı zarar ve tehlike hukuki değerin ilişkili olduğu suçun konusunun zarara ve tehlikeye düşürülmesi olmalıdır ve hukuki konunun ihlali zarar veya tehlike şeklinde ortaya çıkabilmektedir.

Esasen maddi konunun anlamını kaybettiği bütün bu durumlarda 'zaruri olarak zarar ve tehlike suçlarındaki ayrım, hukuki konunun zararı veya tehlikeye düşürülmesi olarak anlaşılmalıdır ${ }^{96}$ görüşünün de bu bağlamda telif edilerek somut olayda hukuki değeri temsil eden objenin zarar ve tehlikeye uğratılması düşüncesini savunmak hukuken daha tutarlı olacaktır.

Görüldüğü üzere zararın maddi konu üzerindeki etkiye göre değerlendirilmesi birçok suç tipini açıklamakta yetersiz kalmaktadır. Özellikle hırsızlık ve yağma gibi suç tiplerinde çalınan eşyanın zarar görmesinden bahsedilemez; zarar gören, somut olayda kişinin mülkiyet hakkı ile koruma altına alınan malvarlığıdır. Dolayısı ile suçun maddi konusu somut bir fiilde çalınan cep telefonu iken bu cep telefonu zarara uğramamakta zarara uğrayan kişinin eksildiği için malvarlığı olmaktadır. Bu somut olayda da esasen hukuki değerin ilişkin olduğu konuyu yani suçun konusunu malvarlığı oluşturmaktadır. Aynı şekilde resmi belgede sahtecilik suçunda tehlikeye düşen, suçun konusu olan belge değil kamu güvenidir. ${ }^{97}$ Yine belgede sahtecilik suçlarında hukuken

Heinegg, StGB Kommentar, 3. Bas1, C.H. Beck, 2018, s. 2181.

95 Rönnau, s. 962. Bizim hukukumuz açısından bir evin yakılmasıyla veya tahrip edilmesiyle, şayet ev bir başkasının mülkiyetinde ise ve sahibinin rızası yoksa, mala zarar verme suçu işlenmiş olur. Bu suç bir netice suçudur. Ancak, bu suçun işlenmesiyle başkalarının hayatı, vücut bütünlüğü ve malvarlığı da tehlikeye sokulmuş olabilir. Bu yönü itibarıla bir tehlike suçundan söz edebiliriz. Ancak bu suç, Alman Kanunu'ndan farklı olarak, TCK'da bir somut tehlike suçu olarak tanımlanmıştır. Bu tehlike suçunun oluşabilmesi için yakılan veya tahrip edilen malın bir başkasına ait olması gerekmemektedir.

96 Stratenwerth / Kuhlen, s. 76.

97 Ömer Metehan Aynural, Soyut Tehlike Bağlamında Trafik Güvenliğini Tehlikeye Sokma 
geçerli olan belge üzerinde bir sahtecilik yapılması halinde suçun maddi konusu kriteri işe yarayabilmekte ve bu suç maddi konu zarara uğradığı için bir zarar suçu olarak tanımlanabilmektedir. Ancak belgenin , "sahte olarak düzenlenmek" (TCK. m. 204, 207), "yalan beyanda bulunmak" (TCK. m. 206) veya "gizlemek" (TCK. m. 205, 208) suretiyle işlenmesinde belgenin zarar veya tehlikeye uğraması söz konusu olmamaktadır. O halde zarar veya tehlike suçlarını suçun (maddi) konusunun etkileniş derecesi ve şekli olarak tanımlamak da herhalde isabetli olmamaktadır. ${ }^{98} \mathrm{Bu}$ suçun işlenmesi ile ihlal edilen hukuki değer, hukuki ilişkilerin belgelerle sağlamlığının ve güvenliğinin sağlanmasıdır. ${ }^{99}$ Zarar ve tehlikeye düşürülen ise bir hukuki ilişkiye katılacak kimsenin güven duygusudur. ${ }^{100}$

Bu iddiayı teyit eden örneği TCK'da da bulmak mümkündür. Nitekim "genel güvenliğin kasten tehlikeye sokulması suçu", 5237 sayılı TCK'nın “Topluma Karşı Suçlar” başlıklı üçüncü kısmının "Genel Tehlike Yaratan Suçlar" başl1klı birinci bölümünde, Kanun'un 170. maddesinde düzenlenmiştir. İlgili hüküm şu şekildedir:

"Kişilerin hayatı, sağllğg veya malvarlı̆g bakımından tehlikeli olacak biçimde ya da kişilerde korku, kaygı veya panik yaratabilecek tarzda;

a) Yangı̀ çıkaran,

b) Bina çökmesine, toprak kaymasına, çı̆̆ düşmesine, sel veya taşkına neden olan,

c) Silâhla ateş eden veya patlayıcı madde kullanan kişi, altı aydan üç yıla kadar hapis cezast ile cezalandırılır."

Suçu, XII Levha Yayınları, 2018, s. 21.

98 Erdin, Ceza Hukukunda İlliyet, s. 43. Mala zarar verme suçunda suçun konusu zarar verilen taşınır veya taşınmaz maldır. Suçun neticesi bu mala zarar verilmesi , mala zarar vermek suretiyle, suçla korunan hukuki değerin ilişkili olduğu konu olan malvarlığında da bir zarar meydana gelmektedir. Bu bakımdan suçun işlenmesiyle suçun konusunun zarar veya tehlikeye uğruyor olması, onun zarar veya tehlike suçu olmasının sebebi değildir. Zarar suçu-tehlike suçu ayrımı, korunan hukuki değerin ilişkili olduğu konun zarar veya tehlikeye uğramasına göre tayin edilecektir. Ayrıca bkz. s. 44. dn. 211. Yazara katılmakla beraber esasen korunan "hukuki değere ilişkin konu"nun "suçun konusu" içerisinde şerh edilmesi gerektiği görüşünde olduğumuzu yukarıda belirtmiştik.

99 Gunther Artz / Ulrich Weber / Bernd Heinrich / Eric Hilgendorf, Strafrecht Besonderer Teil, 3. Bas1, Gieseking Verlag, 2015, s. 929.

100 Artz/Weber/Heinrich/Hilgendorf, s. 929. 
Tipiklik unsuru analiz edildiğinde, yangın çıkarma ve bina çökmesi, toprak kayması, çığ düşmesi, sel taşkınına neden olma gibi fiillerle suçun esasında neticeli bir somut tehlike suçu olarak düzenlendiği anlaşılmaktadır. Maddi konunun zarar ve tehlikeye düşürülmesi açısından yaklaşılacak olursak bir neticeli zarar suçu; fakat hukuki konu açısından yaklaşılacak olursak kanun koyucunun amaçladığı şekilde somut tehlike suçu karşımıza çıkmaktadır. ${ }^{101}$ Çünkü kanun koyucu kişilerin hayatını, sağlığını ve malvarlığını koruma amacı gütmektedir. Burada suçun konusu esasen yangın, bina çökmesi, toprak kayması, çığ düşmesi, sel ve taşkın ya da silah ve patlayıcı madde ile hayatı sağlığı ve malvarlığı tehlikeye düşen korku, kayg1 ve panik yaşayan kimselerdir. Kişinin kendi arazisinde yangın çıkarma veya kendi binasını çökertme hakkı bulunmamaktadır. Suçun maddi konusu yangın çıkarılan şey veya çökertilen bina bile olsa suçun konusu somut durumda bunlardan etkilenen kişilerdir. Dolayısı ile bu suç suçun maddi konusu (Tatobjekt) açısından bir neticeliłzarar suçu olarak tanımlanması hukuken hatalı olacaktır. Suçun konusu açısından bu suç somut bir tehlike suçudur. Bu suç ile korunan hukuki değer başkalarının tehlikesiz bir yaşama sahip olma hakkıdır.

Söz konusu iddia hazırlık hareketlerini cezalandıran kimi soyut tehlike suçları üzerinden daha da derinleştirilebilir. Bu suçlarda kanun koyucu birçok eleştiri almasına rağmen esasında daha sonra gerçekleştirilmesi planlanan bir hukuki konu ihlali için cezalandırma yoluna gitmiştir. Bu suçlarda hazırlık hareketi cezalandırılmasına rağmen dış dünyada belirlenebilir bir etkinin neticenin olması kayıt altına alınmaktadır. Bu bağlamda Alman kanunun 202c maddesi örnek olarak verilebilir. Bu maddede esasen veri casusluğu ve verilerin iletilirken ele geçirilmesinin hazırllğı yapılmakta ve bu hazırlık hareketleri cezalandırılmaktadır. ${ }^{102} \mathrm{Bu}$ maddeye göre kişi, özel olarak korunmuş verilere giriş yapmaya çalışır, şifre ve sair güvenlik kodlarını ve bu tür fiilleri işlemeye yarayan bilgisayar programlarını üretir, kendisine ve başkasına sağlar, satar, bir başkasına verir, yayar veya sair bir şekilde ulaşılmasını sağlarsa cezalandırılmaktadır. Bu suç tipinde de esasında bir kişinin gizli kalması konusunda hukuki menfaati olan verilere ilişkin ihlal henüz ortaya çıkmamış; bu fiillerin akabinde veya bilinmeyen bir mesafede ortaya çıkacak olsa da esasen tipik netice gerçekleşmiştir. ${ }^{103}$ Ancak suç

101 Bkz. TCK 170. maddenin gerekçesi, in. Erdener Yurtcan, Yeni Türk Ceza Kanununu ve Yorumu, 2. Bası, Kazanc1 Yayınları, 2006, s. 306.

102 Goeckenjan, s. 50-51., Heintchel-Heinegg, s. 1306 vd.

103 Goeckenjan, s.51. 
korunan hukuki değerin objesi açısından bir soyut tehlike suçu olarak değerlendirilmektedir. ${ }^{104} \mathrm{Bu}$ suç tipinde de temel olarak fiilin yönelik olduğu suçun maddi konuları olan şifreler, güvenlik kodları ve bilgisayar programları açısından bir değerlendirme yapılmamakta, bilakis hukuki değerin korumaya aldığ 1 obje/suçun konusu üzerinden suç, soyut tehlike suçu en nihayetinde neticeli bir soyut tehlike suçu olarak ortaya çıkmaktadır.

Benzer bir değerlendirmeyi Türk Ceza Kanunu bakımından da yapmak mümkündür.

"TCK Madde 245/A- (Ek: 24/3/2016-6698/30 md.) (1) Bir cihazın, bilgisayar programinın, şifrenin veya sair güvenlik kodunun; münhasiran bu Bölümde yer alan suçlar ile bilişim sistemlerinin araç olarak kullanılması suretiyle işlenebilen diğer suçların işlenmesi için yapılması veya oluşturulması durumunda, bunlart imal eden, ithal eden, sevk eden, nakleden, depolayan, kabul eden, satan, satışa arz eden, satın alan, başkalarına veren veya bulunduran kişi, bir yıldan üç yıla kadar hapis ve beşbin güne kadar adli para cezasi ile cezalandirllır."

Hükmünü düzenlemektedir. Suçun maddi konusu cihaz, bilgisayar programı, şifre veya sair güvenlik kodu olsa bile bunların bulundurulması veya oluşturulması ile veya imali, ithali, sevki, nakli, depolanması, kabulü, satışı, satışa arzı, başkalarına verilmesi, bulundurulması ile esasen söz konusu cihazlar, bilgisayar programları şifreler ve sair güvenlik kodları zarar ve tehlikeye uğramamaktadır. Burada zarar ve tehlikeye uğrayan bilişim suçları bağlamında korumaya alınmış başta veri olmak üzere bilişim sistemleri ve diğer şeylerdir. Bu bakımdan suç soyut tehlike suçudur. Bu bağlamda ilgili suç, maddi konu ile suçun konusu arasındaki farklılaşmaya örnek olarak verilebilir.

\section{Sonuç}

Bir suçun sırf hareket suçu mu yoksa neticeli bir suç mu bu bağlamda zarar suçu mu yoksa tehlike suçu mu olduğunun uygulama açısından teorik tartışmalardan öte anlamları bulunmaktadır. Bunlar, illiyet bağı ve objektif isnadiyete ilişkin tartışmalar, suçun işlendiği yer, suça teşebbüsün uygulama alanı bulunup bulunmayacağ 1 gibi önemli konulardır. Neticenin doğal anlamıyla algılanmasıyla suçlar sırf hareket suçları ve neticeli suçlar olarak ikiye ayrılmaktadır. Her hareketin bir dış etkisinin olduğu iddiası doğru olsa

104 Heintchel-Heinegg, s. 1317, Goeckenjan, s. 51. 
bile bu kendisine bir hukuki sonuç bağlanmadığ1 sürece önem arz etmez. $\mathrm{Bu}$ bakımdan hareketten hasıl olan ve zaman ve mekân olarak hareketten ayrilabilen ve kendisine tipiklikte yer bulmayan neticeler ceza hukuku bakımından netice olarak kabul edilemez.

Ceza hukuku bakımından maddi konu, suçların yorumu ve uygulaması açısından son derece önemlidir. Ancak maddi konu ve bir hukuki değerin ait olduğu obje ile ilişkilendirilmemiş suçun konusu tanımlaması, kendi üzerinden bir suç kategorisi yaratmaya elverişli değildir. Çünkü birçok suçta esasen bir maddi konu yoktur. Maddi konunun bulunmadığı noktalarda sosyal değerlerin ikamesiyle sorun ortadan kaldırılmaya çalışılmaktadır ve hukukumuzdaki ağırlıklı görüş doğrultusunda sadece bu yönüyle maddi konudan ayrılmaktadır. $\mathrm{Bu}$ hâlde ise esasen maddi konunun kendisi önemini kaybetmektedir. Bahsi geçen çözümle ihlal edilen şey aslında çoğunlukla hukuki konu olmaktadır. Maddi konunun zarara veya tehlikeye düşürülmesine göre suçların zarar ve tehlike suçu kategorilerine ayrılması, öncelikle her suçta maddi konunun olmadığına ilişkin hususun gözden kaçırılması hatasına dayanmaktadır. Maddi konunun kategori oluşturma konusundaki elverişsizliğinin bir diğer sebebi, hukuki değerin konusu ile suçun maddi konusunun her suç açısından aynı olmadığ 1 -birçok kez olmasına rağmen- hususundaki farkındalık eksikliğidir. ${ }^{105}$ $\mathrm{Bu}$ bakımdan eğer zarar ve tehlike suçu arasında bir ayrım yapılacak ise bu suç ile korunan hukuki değeri de temsil eden suçun konusunun zarar veya tehlikeye uğratılması olarak anlaşılmalıdır. Hukuki değerler zarar ve tehlikeye uğramaz, ancak ihlal edilebilir. Esasen zarara ve tehlikeye uğrayan hukuki değerlerin koruma altına aldığı maddi ve manevi varlıklardır. Suçun konusu tanımı yapılırken öncelikle hukuki değer- hukuki değerin objesi görüşünden hareket edilerek hukuki değer objeleri ile ilişkili bir tanımlama yapmak gerekmektedir.

Öte yandan suç tipinin doğru bir şekilde tanımlanması kimi hukuki kurumların uygulanması bakımından son derece önemlidir. Suç tipi doğru belirlenemez ve yukarıda kundaklama fiili için yapılan açılamaların gösterdiği gibi maddi konu üzerinden bir "neticeli zarar suç"u olarak yorumlanırsa rıza müessesesi yanlış uygulanarak kişinin kendi binası üzerinde pekâlâ yangın çıkarılmasına rıza gösterebileceği ileri sürülebilir. Oysaki suç, doğru olarak hukuki konunun objesi üzerinden suç konusu tanımlanarak "neticeli bir tehlike suçu" olarak yorumlanırsa toplum için tehlikeli bir şekilde yangın

\footnotetext{
105 Stratenwerth / Kuhlen, s. 76
} 
çıkarılarak belirsiz sayıda insanın mülkiyet hakkının değil, yaşam hakkının tehlikeye düşürüldügü öngörülür ve rıza kurumu uygulama alanı bulamaz. $\mathrm{Bu}$ sebeple malikin eşyanın zarar uğratılmasına ilişkin rızasının hukuki bir önemi bulunmamaktadır. ${ }^{106}$

Sırf hareket suçlarında hareketin yapılmasıyla suçun maddi unsuru gerçekleşmiş olmaktadır. Doğal anlamda bir netice tipiklikte öngörülmemiştir. Aynı şekilde soyut tehlike suçlarında da hareketin gerçekleştirilmesiyle suçun maddi unsuru gerçekleştirilmiş olur. Hareketin gerçekleşmesi ile somut tehlike veya zarar şeklinde cezalandırma için gerekli olan dışsal bir etki -ister objektif cezalandırma şartı ister netice olarak tanımlansın- aranmaz. Ancak bu, sırf hareket suçları ile soyut tehlike suçlarının aynı şey olduğuna ilişkin bir yanılg1 doğurmamalıdır. Söz konusu kavramlar, bir suça farklı açılardan yaklaşımla ilgili sınıflandırmalardır. ${ }^{107}$ Ancak yukarıdaki analizden de anlaşılacağı üzere her sırf hareket suçu bir netice aranmaması dolayısıyla bir soyut tehlike suçudur. Ancak her soyut tehlike suçu bir sırf hareket suçu değildir. Pekâlâ, belli bir neticenin gerçekleşmiş tipiklikte öngörülmüş olması nedeniyle suç konusu soyut olarak tehlikeye düşürülmüş olabilir. Bütün bu aç1klamalardan sonra yukarıda belirtilen ve sırf hareket suçları ile soyut tehlike suçlarının aynı şey olduğunu iddia eden görüşlerin aksine şu çıkarımda bulunulabilir: Bütün sırf hareket suçları soyut tehlike suçudur. Ancak bütün soyut tehlike suçları sırf hareket suçu değildir. ${ }^{108}$

\section{KAYNAKÇA}

Akbulut B., Ceza Hukuku Genel Hükümler, 6. Bası, Seçkin Yayınevi, Ankara, 2020.

Alacakaptan U., Suçun Unsurları, 2. Bası, Sevinç Matbaası, Ankara, 1975.

Artuk M. E. / Gökcen A. / Yenidünya C., Ceza Hukuku Genel Hükümler, 9. Bas1, Adalet Yayınevi, Ankara, 2019.

Artz G. / Weber U. / Heinrich B. / Hilgendorf E., Strafrecht Besonderer Teil, 3. Bas1, Gieseking Verlag, 2015.

\footnotetext{
106 Rönnau, s. 963; Kindhäuser, s. 1181.

107 Goeckenjan, s.49.

108 Rönnau, s. 963.
} 
Aynural Ö.M., Soyut Tehlike Bağlamında Trafik Güvenliğini Tehlikeye Sokma Suçu, XII Levha Yayınları, İstanbul 2018.

Bulut İ., Suçta Netice, Yıldırım Beyazıt Üniversitesi Sosyal Bilimler Enstitüsü Yayınlanmamıș Doktora Tezi, Ankara 2020.

Centel N. / Zafer H. / Yenerer Cakmut Ö., Türk Ceza Hukukuna Giriş, 11. Bask1, Beta Yayınevi, İstanbul 2020.

Demirbaş T., Ceza Hukuku Genel Hükümler, 14. Baskı, Seçkin Yayınevi, Ankara, 2019.

Dönmezer S. / Erman S., Nazari ve Tatbiki Ceza Hukuku, Genel Kısım, C. I, 1. Basım, Beta Basım, İstanbul, 1997.

Düzenli H., "Yasa Koyucunun Suç ve Ceza Siyasetini Belirleme Yetkisinin Anayasal Denetimi”, Çankaya Üniversitesi Hukuk Fakültesi Dergisi: Arş. Gör. Ceren Damar Şenel Armağanı, 2020, 5 (1), s. 1191-1229.

Erdin S., Ceza Hukukunda İlliyet, Marmara Üniversitesi Sosyal Bilimler Enstitüsü Basılmamış Yüksek Lisans Tezi, İstanbul 2013.

Erem F. / Danışman A. / Artuk M. E., Ceza Hukuku Genel Hükümler, 1. Bask1, Seçkin Yayınevi, Ankara, 1997.

Ersoy U., "Ceza Hukukunun Gri Alanı: Tehlike Suçları", 2020, 41, Y. 11, TAAD, s. 27-60.

Ersoy U, "Hareketin ve Neticenin Haksızlığı Kavramları Işığında Taksirli Suçlarda Meydana Gelen Sonucun Hukuki Niteliği Üzerine Bir İnceleme", 2018, 13 (36), CHD, s. 21 - 32.

Ertem B., "Ceza Hukukuna Hakim Olan İlkeler Açısından Bankacılık Zimmeti Suçu", 5. Türk-Kore Ceza Hukuku Günleri Karş1laştırmalı Hukukta Ekonomik Suçlar Uluslararası Sempozyumu, Ankara, 23.09.2019.

Goeckenjan I., Revision der Lehre von der objektiven Zurechnung, 1. Bas1, Mohr Siebeck, Tübingen 2017.

Hafızoğulları Z. / Özen M., Türk Ceza Hukuku Genel Hükümler, 12. Bası, Us-A Yayınları, Ankara, 2019.

Heintchel-Heinegg Bend, StGB Kommentar, 3. Bas1, C.H. Beck, 2010.

Hoyer A., Strafrecht Allgemeiner Teil, 1. Bas1, Hermann Luchterhand Verlag, Luchterhand, 1996. 
Jakobs G., Strafrecht Allgemeiner Teil, 1. Bas1, DeGruyter, Berlin 1983.

Jescheck H. / Weigend T., Lehrbuch Des Strafrechts, Allgemeiner Teil, 5. Bas1, Duncker \& Humblot, Berlin, 1996.

Kaspar J., Strafrecht Allgemeiner Teil, 3. Bas1, Nomos, Baden-Baden, 2019.

Keçelioğlu E., "Ceza Hukukunda İçtihadın Sınırı, Yorum ve Kıyas”, 2012, Y. 3, (11), TAAD, s. 77 - 100.

Keçelioğlu, Elvan: "Risk Toplumunda Ceza Hukukunun Değişen Yüzü”, Prof. Dr. Nevzat Toroslu'ya Armağan, C. 1, Ankara Üniversitesi Yayınları, 2015, s. 627-639.

Kindhäuser U., Strafgesetzbuch Lehr- Und Praxiskommentar (Nomos Kommentar), 4. Bas1, Nomos, Baden-Baden, 2010.

Koca M. / Üzülmez İ., Türk Ceza Hukuku Genel Hükümler, 12. Bası, Seçkin Yayınevi, Ankara, 2019.

Kunter N., Suçun Maddi Unsurları Nazariyesi, İstanbul Üniversitesi Hukuk Fakültesi Yayınları, İstanbul, 1954.

Otto H., Grundkurs Strafrechts, 7. Bas1, De Gruyter, Berlin, 2004.

Önder A., Ceza Hukuku Dersleri, 1. Bası, Filiz Kitabevi, İstanbul, 1992.

Özgenç İ., Türk Ceza Hukuku Genel Hükümler, 15. Bası, Seçkin Yayınevi, Ankara, 2019.

Öztürk B. / Erdem M. R., Uygulamalı Ceza Hukuku ve Güvenlik Tedbirleri Hukuku, 19. Bası, Seçkin Yayınevi, Ankara, 2019.

Rotsch T., "Einheitstaeterschaft" Statt Tatherrschaft, Mohr Siebeck, Tübingen, 2009.

Roxin C., Strafrecht Allgemeiner Teil Band I, 4. Bas1, C.H.Beck, München, 2006.

Roxin C. Strafrecht Allgemeiner Teil Band II, 4. Bası, C.H.Beck, München, 2006.

Rönnau T., "Grundwissen - Strafrecht: Erfolgs- Und Tätigkeitsdelikte", Jus, 2010, , 2010, 11, JuS, s. 961- 963.

Sarıtaş E., Suç İşlemek İçin Örgütlenme Suçları, 1. Bası, On İki Levha Yayınları, İstanbul, 2018. 
Schmidhäuser E., Strafrecht Allgemeiner Teil, 2. Bası, Mohr Verlag, Tübingen 1975.

Soyaslan D., Ceza Hukuku Genel Hükümler, 8. Bası, Yetkin Yayınevi, Ankara, 2018.

Stratenwert G. / Kuhlen L., Strafrecht Allgemeiner Teil, 6. Bas1, Vahlen, München, 2011.

Toroslu N., Cürümlerin Tasnifi Bakımından Suçun Hukuki Konusu, 1. Bası, Savaş Yayınevi, Ankara 2019.

Toroslu N. / Toroslu H., Ceza Hukuku Genel Kısım, 25. Bası, Savaş Kitabevi, Ankara, 2019.

Ünal O.G., Türk Ceza Hukuku'nda Tehlike Suçları, Yayımlanmamış Doktora Tezi, Ankara Hacı Bayram Veli Üniversitesi Lisansüstü Eğitim Enstitüsü, 2020.

Ünver Y., Ceza Hukukuyla Korunması Amaçlanan Hukuksal Değer, Seçkin Yayınevi, Ankara, 2003.

Walter T., "Das Märchen Von Den Tätigkeitsdelikten", Christian Fahl U. A. (Hg.), Festschrift für Werner Beulke Zum 70. Geburtstag, Heidelberg 2015, s. 327-338.

Wessels J. / Hettinger M., Strafrecht Besonderer Teil, C. I, 29. Bas1, C.F. Müller, Heidelberg, 2005.

Wessels J./ Beulke W. /Setzger H., Strafrecht Alllgemeiner Teil, 45. Bas1, C.F. Müller, Heidelberg 2015.

Yenisey F. / Plagemann G., Alman Ceza Kanunu Strafgesetzbuch, Beta Yayınevi, İstanbul 2009.

Yurtcan E., Yeni Türk Ceza Kanununu ve Yorumu, 2. Bas1, Kazanc1 Yayınları, İstanbul, 2006.

Zafer H., Ceza Hukuku Genel Hükümler, 4. Bası, Beta Basımevi, İstanbul, 2015. 